\title{
Current status of genus Impatiens: Bioactive compounds and natural pigments with health benefits
}

\author{
Eleomar O. Pires Jr. ${ }^{a, b}$, Cristina Caleja ${ }^{a, * *}$, Carolina C. Garcia ${ }^{b}$, Isabel C.F.R. Ferreira ${ }^{a}$, \\ Lillian Barros ${ }^{\text {a, * }}$ \\ ${ }^{\text {a }}$ Centro de Investigação de Montanha (CIMO), Instituto Politécnico de Bragança, Campus de Santa Apolónia, 5300-253, Bragança, Portugal \\ ${ }^{\mathrm{b}}$ Academic Department of Food (DAALM), Federal Technological University of Paraná, Campus Medianeira, 85884-000, Paraná, Brazil
}

\section{A R T I C L E I N F O}

\section{Keywords:}

Edible flowers

Impatiens

Natural pigments

Bioactivities

Phenolic compounds

\begin{abstract}
A B S T R A T
Background: The market for edible flowers has grown exponentially due to consumers demand. This has been motivated by the concern to include healthier foods in the daily diet, leading to a great interest in these natural matrices. However, and although the consumption of this type of matrices are popularly associated with health benefits, scientific studies are still scarce. The industry seeks to satisfy the consumers demands and, at the same time, seeks to launch new challenges in the sector, in order to outline new conservation and production strategies. Although there are several flowers with edible potential in nature, many are still little explored or unnoticed, so this type of study is increasingly sought after.

Scope and approach: The present review intendeds to explore the context of edible flowers as well as their conditions of production and consumption. Then, focusing on the characterization of the genus Impatiens, which, although is still little explored, gathers data on its chemical and nutritional characterization, bioactivities, and the possible exploration of natural pigments and industrial application.

Key findings and conclusions: Several studies have been focused on the chemical characterization of flowers, evaluation their edibility, as well as validating their bioactive potential. In particular, the genus Impatiens is characterized by presenting perennial and succulent herbs with attractive colors, normally found in tropical forests. There are countless studies on the bioactive activities present in these edible flowers. In addition, its pigmentation has a direct relationship with the presence of several compounds, especially anthocyanins and their derivatives. These bioactive compounds have a great interest to the food industry and consumers, due to their diverse health benefits that are provided by their regular consumption.
\end{abstract}

\section{Introduction}

Flowers have been present in human daily life since ancient times (de Morais et al., 2020; Zheng, Meenu, \& Xu, 2019). Although flowers are usually associated with decorative purposes, there are reports of the presence of flowers as ingredients of different recipes in different cultures around the world (Fernandes, Casal, Pereira, Saraiva, \& Ramalhosa, 2016; Pires, Barros, Santos-Buelga, \& Ferreira, 2019). In addition, studies claim that the universe of application of flowers is very wide, in which they can be applied within different areas, namely for the pharmaceutical, cosmetic and even food sectors (Trinh, Choi, \& Bae, 2018).

Currently, the production of edible flowers, as well as their consumption is growing due to the advent of media interventions and a greater consumer demand for healthy alternatives for food (Koike, Antonio, Ferreira, \& Villavicencio, 2014; Pires et al., 2019). However, from an agronomic point of view, the cultivation for human consumption of these plants still presents challenges, since many flowers, although edible, are produced for the purpose of ornamentation and landscaping (Matyjaszczyk \& Śmiechowska, 2019).

In general, flowers are inserted into the human diet in natura (Matyjaszczyk \& Śmiechowska, 2019). However, several studies have been carried out testing different processes, in order to find effective methodologies in the conservation of their structures without degrading their nutritional composition, and providing the least possible damage in terms of organoleptic characteristics (Pires et al., 2019).

\footnotetext{
* Corresponding authors.

$* *$ Corresponding author.

E-mail addresses: ccaleja@ipb.pt (C. Caleja), lillian@ipb.pt (L. Barros).
} 
The scientific community is increasingly committed to deepening studies on edible flowers, namely the identification and characterization of various bioactive compounds (Zheng, Meenu, \& Xu, 2019), thus becoming an interesting subject of study as functional food products (Gostin \& Waisundara, 2019).

Plants of the genus Impatiens are characterized as perennial and succulent plants which are often found in tropical and subtropical humid forests, especially near river slopes (Szewczyk, Bonikowski, Maciąg-Krajewska, Abramek, \& Bogucka-Kocka, 2018a). They usually have a simple foliage, medium-sized and have attractive colored flowers. Some cultivars of this genus can be easily found in commercial spaces, being normally associated with landscaping functions, ornamentation activities and, occasionally, for human consumption (Kinupp, 2014). It is known that the genus Impatiens is very broad in terms of diversity of species (Yu et al., 2016). Current studies affirm the existence of more than 300 distinct compounds present in several studied species, among them flavonoids, phenolic acids, coumarins, quinones, terpenes, and saponins stand out (Szewczyk, 2018; Li et al., 2017; Kim et al., 2015; Li et al., 20015a; Mitchel, Brescia, Smith \& Morgan, 2007; Lobstein et al., 2001). In general, carbohydrates are the main macronutrients present, followed by proteins and lipids (Fernandes et al., 2016). Furthermore, pigments are very common in flower petals, although some species also show colour in their stems, being anthocyanins the main compounds responsible for the colour of these organs. Many of the compounds present in these plants are directly linked to studies related in the prevention and reduction of human pathologies (Imam, Nahar, Akter, \& Rana, 2012). In fact, some species such as Impatiens balsamina L. (1753) and Impatiens walleriana Hook. f. it has been shown a great relevance in the pharmaceutical field (Szewczyk, 2018).

Thus, in this review, some concepts related to the universe of edible flowers will be addressed, such as contextualizing the insertion of these plants in the human diet and reporting the current concepts in relation to the consumption and production of this food segment. Highlighting, in particular, the genus Impatiens, which is still little studied and explored despite its immense potential. This work is the first written bibliographic review that gathers information about chemical and nutritional characteristics of flowers of the genus Impatiens as well as the main bioactive compounds currently identified, and the main benefits provided by their consumption. This review allows us to reflect and explore the possible applications of these edible flowers in the food industry, as a natural ingredient with coloring potential.

\section{Contextualization of edible flowers}

\subsection{Edible flowers: history and customs}

Literature describes the presence of edible flowers in several civilizations since ancient times (Pires et al., 2019). For example, ancient Greek and Roman civilization used flowers as ingredients in making dishes but also in alternative medicine (Mlcek \& Rop, 2011). Then, other studies reported the presence of edible flowers in the medieval era in France, as well as in Victorian England (Liu et al., 2015). While in the Asian continent, flower consumption has been described for thousands of years in countries like China and Japan (Takahashi, Rezende, Moura, Dominguete, \& Sande, 2020). On the American continent, as flowers are always present in the daily lives of indigenous peoples, especially the Aztecs (Newman \& Kirker, 2016).

Several historical fragments describe the relationship between edible flowers and humans (Takahashi et al., 2020). Taraxacum, for example, is quoted in biblical writings as bitter herb used in fresh salads and as an ingredient in bread. Manuscripts in bamboo strips and fragments of silk cited that the Nelumbo nucifera Gaertn. Flower as an ingredient in the composition of several recipes in China (Newman \& Kirker, 2016). Artifacts found in Greece endowed with the year 1500 b.C., showed the existence of the cultivation of flowers such as Cynara scolymus L., Dianthus caryophyllus L. and Papaver rhoeas L. by the Greek peoples
(Takahashi et al., 2020). In one of the expeditions carried out by the Europeans to discover the new world, the Dominican friar Diego Duran described in one of his documents the following sentence: "It would be an understatement to say that the Aztecs liked flowers, they loved them", also confirming the presence of flowers in the Aztecs routine (Newman \& Kirker, 2016).

Edible flowers can be consumed in different ways. They are usually used in typical dishes, as part of rituals and festive events (Takahashi et al., 2020). In India, for example, the consumption of edible flowers from trees was related to the concept of human immortality, just as the Asians believed that ingesting the lotus flowers, would provide a greater balance and longevity throughout life (Newman \& Kirker, 2016; Pinakin, Kumar, Suri, Sharma, \& Kaushal, 2019).

Several customs relating to flower consumption have been reported in the Americas. Pumpkin flowers were included in the making of stews in North America by the Zuni tribe, and hibiscus flowers in South America (Cunningham, 2015; Newman \& Kirker, 2016). In another way, the Aztecs believed that the act of smelling the odor or consuming small fragments of flowers contributed to fight against the sensation of hunger. In Peru, the consumption of two varieties of nasturtium flowers became popular through medicinal application and in salad preparation (Newman \& Kirker, 2016).

In the Europe, flowers made up the banquets of the aristocracy, adorning dishes and drinks (Rop, Mlcek, Jurikova, Neugebaurova \& Vabkova, 2012). In countries like Portugal and Spain, traditional cheeses based on sheep's milk are produced with a coagulant based on the Cynara cardunculus L. flower (Gomes et al., 2019). While in Switzerland, elderly people mention that they remembered their childhood through the consumption of flowers (Abbet et al., 2014).

The adoption of new eating habits, the modernization of society and urbanization are factors that influence customs regarding the consumption of edible flowers. Thus, resulting in a loss of valuable information regarding the benefits provided by the consumption of these plants parts (Abbet et al., 2014; Harmayani et al., 2019). However, Fernandes, Casal, Pereira, Saraiva, and Ramalhosa (2020) states that the market for edible flowers is growing due to globalization, which can raise awareness and encourage consumers to return to previous lifestyles.

\subsection{Current conditions of production and consumption of edible flowers}

Edible flowers are an emerging food class, in which producers are trying to satisfy frequent market demands (de Favari Tardivo \& Meru, 2018; Fernandes et al., 2020). However, many factors such as seasonality and perishability affect the production of this segment (Fernandes et al., 2020). Although similar in their physiological characteristics, flowers intended for food and landscaping are different in terms of cultivation (Matyjaszczyk \& Śmiechowska, 2019). Since, the production of ornamental flowers involves fertilizer applications in dosages that are often harmful to human health, while flowers intended for food are usually the result of organic cultivation (Matyjaszczyk \& Śmiechowska, 2019).

The increase in demand for healthier foods, minimally processed and free from harmful effects, justifies an important scenario for the investment in organic flower cultivation, despite the fact that this segment has a higher cost than conventional cultivation (Fernandes et al., 2020; Pires et al., 2019). In addition, paradigms such as shelf life are recurrent in the daily life of edible flower producers, as many of these plants are fragile and suffer many injuries through stern factors such as inadequate transport, high temperatures and pest attack (Pires et al., 2019).

Another relevant aspect is the community to which these plants are intended, as it is believed that this is a very specific market niche, as they are currently found as components of haute cuisine, in addition to often having a high cost (Fernandes et al., 2016, 2020). In addition, the shelf life of these plants is very short, varying on average from 7 to 10 days, which can affect productivity due to their low resistance to storage 
(Fernandes et al., 2020).

However, studies involving technologies to increase the useful life of these products are already present. Koike (2015), for example, researched the increase in resistance of the flowers of Tropaeolum majus L. submitted to electron beams and gamma radiation, however the results obtained stated that this process allows to increase the useful life of these flowers providing satisfactory improvements for the object of study. It is worth noting that the production of edible flowers requires a lot of effort in terms of labor and prior knowledge. In addition, new technologies regarding transport and conservation must be developed to provide consumers with a higher quality of this product.

Conducting the production of edible flowers is essential to guarantee the safety of its consumers. Odorizzi, Silva Júnior, and Lemos (2014) recommends that the cultivation of these plants should be conducted through organic cultivation or by the restaurant and residence that uses them. Menegaes, dos Santos, and Londero (2014), on the other hand claims, that hydroponic cultivation is a great alternative for this plant segment to produce constant and profitable flowers. In addition, investment in the development of edible flower production is notorious in several locations. Countries like Italy and France have projects for the development of flowers for human consumption (ANTEA, 2019). While in Florida, small producers are seeing good results with flower production, through distribution in local markets, gourmet restaurants and bars (de Favari Tardivo \& Meru, 2018).

There are several reports about the relationship between food security and the consumption of edible flowers. The European Union Rapid Alert System for Food and Feed (EURASFF) alerted the incidence of external contamination in some species of flowers intended for consumption. Among the contaminating agents present, the following were reported: the presence of Salmonella, insect infestations, rat droppings and the presence of unauthorized sulfites. Therefore, precautions must be taken to mitigate certain episodes in order to guarantee the production of safe food (de Favari Tardivo \& Meru, 2018).

Fornefeld et al. (2017), mentioned that the conditions of different crops and processing, can enable the attack of microorganisms in flowers. The inadequate use of fertilizers and pesticides, the poor quality of irrigation water and contaminated soil are some of the external factors prior to flower harvesting, while poor sanitary conditions of handling, transport, distribution and storage are the main problems of post-harvest contamination (Matyjaszczyk \& Śmiechowska, 2019). In addition, many flowers are used fresh to ornament dishes, and even if not ingested, they can cause problems related to cross-contamination with other foods that make up the meal (Matyjaszczyk \& Śmiechowska, 2019).

Currently, the consumption of edible flowers can be observed both in gastronomy, through the composition of dishes and beverages, as well as in industry, through processes of dehydration, crystallization, in obtaining food additives or even in the composition of foods, such as jellies and pastry products (Chen \& Wei, 2017; Fernandes et al., 2020). On the other hand, Rodrigues et al. (2017) points out in his research, that the consumption of edible flowers is currently limited to sophisticated establishments of gastronomy, however it reinforces that the potential of these plants is substantially greater due to their properties. While Pires et al. (2019) states that the flowers are generally consumed in their entirety, but in many cases, only some parts such as petals and buds are ingested, due to the presence of bitterness and inedible parts.

Since, cultural differences and consumption patterns can determine the acceptability of these food classes as "new food" or "unknown food" (Rodrigues et al., 2017). However, studies aim to measure the main factors that drive the consumption of flowers in the human diet (Chen \& Wei, 2017; Rodrigues et al., 2017). In this way, Chen and Wei (2017) states that the aroma and relation to a "healthy food", are some of the decisive factors for flower consumption. Furthermore, the same authors report that floral foods, endowed with proven health benefits, have great potential for exploitation for the food industry.

Carvalho (2018), states that marketing strategies similar to those used for aromatic herbs can be adopted to boost the consumption of edible flowers, as lovers of the aromatic herbs segment have similar characteristics when related to the consumption of edible flowers. In addition, Chen and Wei (2017) state, that the aroma of floral foods, is an aspect that can encourage the consumer to purchase certain products, so it is noted that this aroma provides an emotional appeal of great relevance when it comes to the addition of edible flowers in food matrices. Other studies, on the other hand, report that colour, price and packaging are very important attributes for the purchase of edible flowers and that packages made up of different cultivars and species tend to be more attractive to the consumer (Kelley, Behe, Biernbaum, \& Poff, 2002; Kelley et al., 2001a, 2001b).

As for the current scenario, one can observe the emergence of a new market trend regarding the consumption of edible flowers. This is due to the increase in scientific research, the relationship between flower consumption as a "healthier" diet, greater exposure in media such as social networks and greater insertion in the market, through small producers and chefs (Fernandes et al., 2020). However, Kelley, Cameron, Biernbaum, and Poff (2003) also stated in their study, that although there is no statistical data regarding the consumption of edible flowers, it is evident that this segment is heated due to the increase in the number of cookbook publications and website articles related to the theme, as well as a the growing investigation by the scientific community about the nutritional and chemical composition present in these flowers.

\section{Characterization of impatiens genus}

Impatiens are plants belonging to the balsaminaceae family that are subdivided into approximately 500 species identified (Grey-Wilson, 1980; Morgan, 2007; Szewczyk, 2018). Its name is given due to the "impatient" and explosive behavior of its pods, which when mature hatch due to external mechanical actions and disperse its seeds throughout the environment (Britannica Academic, 2017). They are characterized as perennial, erect herbs, provided with succulent-fleshy stems, they can reach an average of $20-40 \mathrm{~cm}$ in length and are generally found in tropical and subtropical forests, mainly near the river slopes (Kinupp, 2014). They arouse interest due to their colorful and attractive flowers that can change between the white, pink, orange and purple colors (Kinupp, 2014). And despite being made up of thick stems, they have fragility in their petals and leaves that are easily damaged (Britannica Academic, 2017; Grey-Wilson, 1980). Currently, some species are found in the trade selected for landscaping, ornamentation or even for human consumption (Kinupp, 2014). In addition, some studies denote the use of the genus Impatiens by Asian people as an ingredient for alternative medicine, attacks and combating pathologies such as rheumatism, inflammation of nails and treatment of fractures (Wang, Li, \& Bi, 2018).

Some studies point to historical facts about Impatiens specimens. The I. walleriana, for example, have been grown as ornamental plants since the 19th century (CABI, 2020b). Studies also point to the appearance of I. balsamina in India and its spread through Southeast Asia, while in Europe its ornamental use has been dated since the 16th century (CABI, 2020a). I. glandulifera Royle, conquered the European continent from the United Kingdom, spreading due to its use by beekeepers and through the dispersion of its seeds along the course of rivers (CABI, 2020c). In addition, the vast spread of these species has led to their naturalization in countries such as Finland, Czech Republic, Switzerland and Germany (CABI, 2020c). Meanwhile, the first reports about I. parviflora DC. in the wild were present in the year 1831, in the botanical garden of Genfe, Switzerland (CABI, 2020d). However, nowadays many species of Impatiens can be considered weeds in some regions of Europe (Britannica Academic, 2017). According to Grey-Wilson (1980), the genus Impatiens is present mainly in the flora of the Old World, in the most diverse places, such as in territories of tropical Africa and in Southeast Asia, in addition to propagating in temperate regions of Europe, Russia, China 
Table 1

Characteristics present in species of the genus Impatiens.

\begin{tabular}{|c|c|c|c|c|c|c|c|}
\hline $\begin{array}{l}\text { Scientific } \\
\text { Name }\end{array}$ & Synonyms & Native Range & Habitat & Flowers & $\begin{array}{l}\text { Height } \\
(\mathrm{m})\end{array}$ & $\begin{array}{l}\text { Edible } \\
\text { Parts }\end{array}$ & Uses \\
\hline $\begin{array}{l}\text { Impatiens } \\
\text { arguta } \\
\text { Hooker and } \\
\text { Thomson } \\
\text { (1859). }\end{array}$ & $\begin{array}{l}\text { Impatiens arguta var. } \\
\text { bulleyana Hook. f.; } \\
\text { Impatiens gagei Hook.f.; } \\
\text { Impatiens namchabarwensis } \\
\text { R.J. Morgan, YM Yuan e XJ } \\
\text { Ge; Impatiens taliensis } \\
\text { Lingelsh. \& Borza (The } \\
\text { Plant List, 2013). }\end{array}$ & $\begin{array}{l}\text { Native to parts of } \\
\text { Asia (China, Bhutan, } \\
\text { north east India, } \\
\text { Myanmar and } \\
\text { Nepal) (Matthews } \\
\text { et al., 2015). }\end{array}$ & $\begin{array}{l}\text { In damp shady places } \\
\text { along the path ( } \\
\text { Matthews et al., 2015). }\end{array}$ & $\begin{array}{l}\text { The inflorescences have } \\
\text { one or two flowers with } \\
\text { very short peduncles. } \\
\text { The large or medium } \\
\text { flowers are pink or } \\
\text { purple red (Matthews } \\
\text { et al., 2015). }\end{array}$ & 0.7 & $\begin{array}{l}\text { Leaves ( } \\
\text { PFAF, } \\
\text { 2020). }\end{array}$ & $\begin{array}{l}\text { Boiled or cooked with } \\
\text { meat (PFAF, 2020). }\end{array}$ \\
\hline $\begin{array}{l}\text { Impatiens } \\
\text { aurella } \\
\text { Rydb. }\end{array}$ & No synonyms are recorded. & $\begin{array}{l}\text { North America } \\
\text { (British Columbia) } \\
\text { and the northwest } \\
\text { United States ( } \\
\text { Batten, 2015; } \\
\text { Klinkenberg, 2013). }\end{array}$ & $\begin{array}{l}\text { Damp thickets and } \\
\text { springy places (PFAF, } \\
\text { 2020; Useful Tropical } \\
\text { Plants, 2016). }\end{array}$ & $\begin{array}{l}\text { Flowers yellow to } \\
\text { orange, with or without } \\
\text { spots, spur strongly } \\
\text { curved (Washington } \\
\text { State, 2020a). }\end{array}$ & $\begin{array}{l}0.5 \text { to } \\
1.0\end{array}$ & $\begin{array}{l}\text { Leaves } \\
\text { and seed ( } \\
\text { PFAF, } \\
\text { 2020). }\end{array}$ & $\begin{array}{l}\text { Cooked (young shoots), } \\
\text { Medicinal (Antidote, } \\
\text { parasiticide, stings and } \\
\text { warts) (PFAF, 2020). }\end{array}$ \\
\hline $\begin{array}{l}\text { Impatiens } \\
\text { balfourii } \\
\text { Hook.f. }\end{array}$ & No synonyms are recorded. & $\begin{array}{l}\text { Native to Himalaya } \\
\text { (India, Nepal and } \\
\text { Pakistan) (Matthews } \\
\text { et al., 2015) }\end{array}$ & $\begin{array}{l}\text { Locality with a high } \\
\text { incidence of light, } \\
\text { invading abandoned } \\
\text { places and with waste } \\
\text { disposal, can also be } \\
\text { found in humid places, } \\
\text { clearings and meadows } \\
\text { (Matthews et al., } \\
\text { 2015). }\end{array}$ & $\begin{array}{l}\text { They are composed of } \\
\text { five petals, in which the } \\
\text { lower two are fused, } \\
\text { forming two compound } \\
\text { flanges. Its coloration } \\
\text { can vary from white, } \\
\text { pink to shades of red ( } \\
\text { Matthews et al., 2015). }\end{array}$ & $\begin{array}{l}0.4 \text { to } \\
0.8\end{array}$ & - & - \\
\hline $\begin{array}{l}\text { Impatiens } \\
\text { balsamina } \\
\text { L. (1753). }\end{array}$ & $\begin{array}{l}\text { Balsamina angustifolia } \\
\text { Blum; Balsamina coccinea } \\
\text { (Sims) DC.; Balsamina } \\
\text { cornuta (L.) DC.; Balsamina } \\
\text { foeminea Gaertn.; } \\
\text { Balsamina hortensis Desp.; } \\
\text { Balsamina lacca Medik.; } \\
\text { Balsamina minutiflora } \\
\text { Span.; Balsamina mollis G. } \\
\text { Don; Impatiens balsamina } \\
\text { var. corymbosa Santapau; } \\
\text { Impatiens coccinea Sims; } \\
\text { Impatiens cornuta L.; } \\
\text { Impatiens eriocarpa Launert; } \\
\text { Impatiens stapfiana Gilg ( } \\
\text { The Plant List, 2013). }\end{array}$ & $\begin{array}{l}\text { India (Matthews } \\
\text { et al., 2015). }\end{array}$ & $\begin{array}{l}\text { Gardens, roads, dumps, } \\
\text { fields, forest edges, } \\
\text { grasslands, riverbeds, } \\
\text { vacant lots, homes and } \\
\text { cemeteries (PFAF, } \\
\text { 2020; Useful Tropical } \\
\text { Plants, 2016). }\end{array}$ & $\begin{array}{l}\text { Its inflorescence can be } \\
\text { of a single flower or with } \\
\text { two or three flowers. The } \\
\text { flowers are usually } \\
\text { white, pink or purple } \\
\text { and have single and } \\
\text { double petals (CABI, } \\
\text { 2020). }\end{array}$ & 0.6 to 1 & $\begin{array}{l}\text { Leaves, } \\
\text { oil and } \\
\text { seed ( } \\
\text { PFAF, } \\
2020) .\end{array}$ & $\begin{array}{l}\text { Dyestuffs, Ornamental, } \\
\text { Medicinal (Tradicional/ } \\
\text { Folklore) (CABI, 2020). }\end{array}$ \\
\hline $\begin{array}{l}\text { Impatiens } \\
\text { bicolor } \\
\text { Royle }\end{array}$ & $\begin{array}{l}\text { Impatiens amphorata } \\
\text { Edgew.; Impatiens } \\
\text { amphorata Edgew. var. } \\
\text { umbrosa (Edgew.) Hook. f.; } \\
\text { Impatiens pallens Edgew.; } \\
\text { Impatiens picta Knowl. \& } \\
\text { Westc; Impatiens roylei } \\
\text { Klotzsch; Impatiens umbrosa } \\
\text { Edgew (Ganeshaiah et al., } \\
\text { 2020). }\end{array}$ & $\begin{array}{l}\text { Western Himalayas ( } \\
\text { Ganeshaiah et al., } \\
\text { 2020). }\end{array}$ & $\begin{array}{l}\text { Shaded slopes ( } \\
\text { Ganeshaiah et al., } \\
\text { 2020). }\end{array}$ & $\begin{array}{l}\text { An inflorescence with } \\
\text { several flowers in the } \\
\text { upper parts of the plant. } \\
\text { Pink and yellow flowers } \\
\text { (Ganeshaiah et al., } \\
\text { 2020). }\end{array}$ & $\begin{array}{l}0.3 \text { to } \\
1.0\end{array}$ & - & - \\
\hline $\begin{array}{l}\text { Impatiens } \\
\quad \text { capensis } \\
\quad \text { Meerb }\end{array}$ & $\begin{array}{l}\text { Balsamina capensis (Meerb.) } \\
\text { DC.; Balsamina fulva Ser.; } \\
\text { Impatiens capensis } f \text {. } \\
\text { capensis; Chrysaea biflora } \\
\text { (Walter) Nieuwl. \& Lunell; } \\
\text { Impatiens biflora Walter ( } \\
\text { The Plant List, 2013). }\end{array}$ & $\begin{array}{l}\text { Eastern North } \\
\text { America (Zika, } \\
\text { 2006). }\end{array}$ & $\begin{array}{l}\text { Banks of rivers and } \\
\text { canals, low-lying moist } \\
\text { woodlands, avoiding } \\
\text { acid soils (PFAF, 2020; } \\
\text { Useful Tropical Plants, } \\
\text { 2016). }\end{array}$ & $\begin{array}{l}\text { It has spots on its petals } \\
\text { (although there is a rare } \\
\text { immaculate shape); } \\
\text { Typically, orange, } \\
\text { however, may vary in } \\
\text { colors, such as cream or } \\
\text { pale yellow (Washington } \\
\text { State, 2020a). }\end{array}$ & 1.2 & $\begin{array}{l}\text { Leaves, } \\
\text { seed and } \\
\text { stem ( } \\
\text { PFAF, } \\
2020) \text {. }\end{array}$ & $\begin{array}{l}\text { Cooked (young leaves } \\
\text { and shoots), Medicinal } \\
\text { (Antidotes, poutice, } \\
\text { stings and warts) (PFAF, } \\
2020 \text { ). }\end{array}$ \\
\hline $\begin{array}{l}\text { Impatiens } \\
\text { edgeworthii } \\
\text { Hook.f. }\end{array}$ & $\begin{array}{l}\text { Impatiens chrysantha Hook. } \\
\text { F. (The Plant List, 2013). }\end{array}$ & $\begin{array}{l}\text { Indian sub-continent } \\
\text { and north-western } \\
\text { Himalaya (Matthews } \\
\text { et al., 2015). }\end{array}$ & $\begin{array}{l}\text { Forest openings, } \\
\text { ditches near water } \\
\text { drains (PFAF, 2020; } \\
\text { Useful Tropical Plants, } \\
\text { 2016). }\end{array}$ & $\begin{array}{l}\text { They are generally } \\
\text { yellowish in color with } \\
\text { red stripes, have an } \\
\text { average size of } 2.5-3.6 \\
\text { cm and their colors vary } \\
\text { between shades of violet, } \\
\text { yellow and white ( } \\
\text { Matthews et al., 2015). }\end{array}$ & 0.6 & - & $\begin{array}{l}\text { Essential oil (PFAF, } \\
\text { 2020). }\end{array}$ \\
\hline \multirow[t]{2}{*}{$\begin{array}{l}\text { Impatiens } \\
\text { flanaganae } \\
\text { Hemsl. }\end{array}$} & $\begin{array}{l}\text { No synonyms are recorded. ( } \\
\text { The Plant List, 2013). }\end{array}$ & $\begin{array}{l}\text { South African } \\
\text { (Pondoland, Eastern } \\
\text { Cape province and } \\
\text { Kwazulu-Natal } \\
\text { province) (Matthews } \\
\text { et al., 2015). }\end{array}$ & $\begin{array}{l}\text { It grows in wooded } \\
\text { areas, floodplains with } \\
\text { partial shade, along the } \\
\text { banks of rivers and } \\
\text { gullies (Matthews } \\
\text { et al., 2015). }\end{array}$ & $\begin{array}{l}\text { Inflorescence of pink } \\
\text { color composed between } \\
6 \text { and } 15 \text { flowers and } \\
\text { supported by a } \\
\text { pendulum of } 17-39 \mathrm{~cm} \text { ( } \\
\text { Matthews et al., 2015). }\end{array}$ & $\begin{array}{l}1.0 \text { to } \\
2.0\end{array}$ & - & - \\
\hline & $\begin{array}{l}\text { Balsamina glandulifera } \\
\text { (Royle) Ser.; Balsamina }\end{array}$ & $\begin{array}{l}\text { Himalays, north- } \\
\text { west Pakistan and }\end{array}$ & $\begin{array}{l}\text { Riverbanks, moist } \\
\text { natural forests, forest }\end{array}$ & $\begin{array}{l}\text { They have } 5 \text { petals ( } 2 \\
\text { fused, } 3 \text { sepals). Their }\end{array}$ & $\begin{array}{l}0.5 \text { to } \\
2.5\end{array}$ & $\begin{array}{l}\text { Leaves, } \\
\text { oil and }\end{array}$ & $\begin{array}{l}\text { Garden ornamental; } \\
\text { honey plant and Bach } \\
\text { (continued on next page) }\end{array}$ \\
\hline
\end{tabular}


Table 1 (continued)

\begin{tabular}{|c|c|c|c|c|c|c|c|}
\hline $\begin{array}{l}\text { Scientific } \\
\text { Name }\end{array}$ & Synonyms & Native Range & Habitat & Flowers & $\begin{array}{l}\text { Height } \\
(\mathrm{m})\end{array}$ & $\begin{array}{l}\text { Edible } \\
\text { Parts }\end{array}$ & Uses \\
\hline $\begin{array}{l}\text { Impatiens } \\
\quad \text { glandulifera } \\
\text { Royle }\end{array}$ & $\begin{array}{l}\text { macrochila (Lindl.) Ser.; } \\
\text { Balsamina roylei (Walp.) } \\
\text { Ser.; Impatiens macrochila } \\
\text { Lindl.; Impatiens roylei } \\
\text { Walp. (The Plant List, } \\
\text { 2013). }\end{array}$ & $\begin{array}{l}\text { north India and } \\
\text { Nepal (Matthews } \\
\text { et al., 2015). }\end{array}$ & $\begin{array}{l}\text { plantations, forest } \\
\text { clearings, railway } \\
\text { landfills, landfills, } \\
\text { urban areas and wet } \\
\text { meadows (PFAF, 2020; } \\
\text { Useful Tropical Plants, } \\
\text { 2016). }\end{array}$ & $\begin{array}{l}\text { colors can vary from } \\
\text { purple, pink or white ( } \\
\text { Washington State, } \\
\text { 2020a). }\end{array}$ & & $\begin{array}{l}\text { seed ( } \\
\text { PFAF, } \\
\text { 2020). }\end{array}$ & $\begin{array}{l}\text { flower remedies (CABI, } \\
\text { 2020). }\end{array}$ \\
\hline $\begin{array}{l}\text { Impatiens noli- } \\
\text { tangere } \mathrm{L} .\end{array}$ & $\begin{array}{l}\text { Balsamina lutea Delarbre; } \\
\text { Balsamina noli-tangere (L.) } \\
\text { Scop.; Impatiens komarovii } \\
\text { Pobed. (The Plant List, } \\
\text { 2013). }\end{array}$ & $\begin{array}{l}\text { United Kingdom } \\
\text { (Lake District) and } \\
\text { Wales (Hatcher, } \\
\text { Wilkinson, Albani, \& } \\
\text { Hebbern, 2004). }\end{array}$ & $\begin{array}{l}\text { Streams, wet ground, } \\
\text { woods (PFAF, 2020; } \\
\text { Useful Tropical Plants, } \\
\text { 2016). }\end{array}$ & & $\begin{array}{l}0.4 \text { to } \\
0.8\end{array}$ & $\begin{array}{l}\text { Leaves } \\
\text { and seed ( } \\
\text { PFAF, } \\
2020) \text {. }\end{array}$ & $\begin{array}{l}\text { Cooked (young shoots), } \\
\text { Medicinal (Antidote, } \\
\text { parasiticide, stings and } \\
\text { warts), Other uses } \\
\text { (yellow colorant, hair } \\
\text { rinse for itchy scalps) ( } \\
\text { PFAF, 2020). }\end{array}$ \\
\hline $\begin{array}{c}\text { Impatiens } \\
\text { pallida } \\
\text { Nuttal }\end{array}$ & $\begin{array}{l}\text { Impatiens pallida } f \text {. pallida ( } \\
\text { The Plant List, 2013). }\end{array}$ & $\begin{array}{l}\text { North America } \\
\text { (eastern USA and } \\
\text { Canada) (Barto, } \\
\text { Friese, \& Cipollini, } \\
\text { 2010). }\end{array}$ & $\begin{array}{l}\text { Moist woodland and } \\
\text { wet meadows, usually } \\
\text { on calcareous soils ( } \\
\text { PFAF, 2020; Useful } \\
\text { Tropical Plants, 2016). }\end{array}$ & $\begin{array}{l}\text { The size of the flowers } \\
\text { can vary from } 2.5 \text { to } 4 \\
\mathrm{~cm} \text {, they are composed } \\
\text { of } 5 \text { petals with cream } \\
\text { colors, or less often } \\
\text { yellow (Matthews et al., } \\
2015 \text { ). }\end{array}$ & $\begin{array}{l}1.0 \text { to } \\
1.2\end{array}$ & $\begin{array}{l}\text { Leaves } \\
\text { and seed ( } \\
\text { PFAF, } \\
2020) \text {. }\end{array}$ & $\begin{array}{l}\text { Oriental dishes, } \\
\text { Medicinal (Skin and } \\
\text { Stings) (PFAF, 2020). }\end{array}$ \\
\hline $\begin{array}{l}\text { Impatiens } \\
\text { parviflora } \\
\text { DC. }\end{array}$ & $\begin{array}{l}\text { Balsamina parviflora (DC.) } \\
\text { Ser. (The Plant List, 2013). }\end{array}$ & $\begin{array}{l}\text { Native to parts of } \\
\text { Asia (China, } \\
\text { Kazakhstan, } \\
\text { Mongolia, Russian } \\
\text { Federation, and } \\
\text { Afghanistan) ( } \\
\text { Washington State, } \\
\text { 2020b). }\end{array}$ & $\begin{array}{l}\text { Forests, forest edges, } \\
\text { moist and humid } \\
\text { forests, beech forests, } \\
\text { settlements (PFAF, } \\
\text { 2020; Useful Tropical } \\
\text { Plants, 2016). }\end{array}$ & $\begin{array}{l}\text { Two types of flowers can } \\
\text { be found in the species } \\
\text { (closed and open for } \\
\text { cross-pollination), with a } \\
\text { pale-yellow color, and } \\
\text { usually also have reddish } \\
\text { spots (Washington State, } \\
\text { 2020a). }\end{array}$ & $\begin{array}{l}0.2 \text { to } \\
1.5\end{array}$ & $\begin{array}{l}\text { Leaves } \\
\text { and seed ( } \\
\text { PFAF, } \\
2020) \text {. }\end{array}$ & $\begin{array}{l}\text { Botanical garden/zoo; } \\
\text { Emergency (famine) } \\
\text { food (CABI, 2020). }\end{array}$ \\
\hline $\begin{array}{l}\text { Impatiens } \\
\quad \text { sulcata Wall }\end{array}$ & $\begin{array}{l}\text { Impatiens gigantea Edgew. ( } \\
\text { The Plant List, 2013). }\end{array}$ & $\begin{array}{l}\text { Temperate } \\
\text { Himalayas, China, } \\
\text { Kashmir, Nepal and } \\
\text { Bhutan (Matthews } \\
\text { et al., 2015). }\end{array}$ & $\begin{array}{l}\text { Soils rich in humus in } \\
\text { forests, shrubs and } \\
\text { cultivated areas, along } \\
\text { canals, humid places in } \\
\text { the shade (PFAF, 2020; } \\
\text { Useful Tropical Plants, } \\
\text { 2016). }\end{array}$ & $\begin{array}{l}\text { Inflorescence with } \\
\text { several flowers, with } \\
\text { pendulum between } 3.5 \\
\text { and } 9 \mathrm{~cm} \text { in length. In } \\
\text { addition to presenting } \\
\text { colors between shades of } \\
\text { pink, red and purple ( } \\
\text { Matthews et al., 2015). }\end{array}$ & 1.5 & $\begin{array}{l}\text { Leaves, } \\
\text { oil and } \\
\text { seed ( } \\
\text { PFAF, } \\
\text { 2020). }\end{array}$ & $\begin{array}{l}\text { Essential oil (PFAF, } \\
\text { 2020). }\end{array}$ \\
\hline $\begin{array}{l}\text { Impatiens } \\
\text { textori Miq. }\end{array}$ & $\begin{array}{l}\text { Impatiens japonica Franch. } \\
\text { \& Sav. (The Plant List, } \\
\text { 2013). }\end{array}$ & $\begin{array}{l}\text { Japan (NYBG, } \\
\text { 2010). }\end{array}$ & $\begin{array}{l}\text { At open and moist } \\
\text { place along a small } \\
\text { stream, in light shade ( } \\
\text { NYBG, 2010). }\end{array}$ & & $\begin{array}{l}0.4 \text { to } \\
0.8\end{array}$ & $\begin{array}{l}\text { Leaves ( } \\
\text { PFAF, } \\
2020) \text {. }\end{array}$ & $\begin{array}{l}\text { Cooked (young shoots) ( } \\
\text { PFAF, 2020). }\end{array}$ \\
\hline $\begin{array}{l}\text { Impatiens } \\
\text { walleriana } \\
\text { Hook. f. }\end{array}$ & $\begin{array}{l}\text { Impatiens giorgii De Wild.; } \\
\text { Impatiens holstii Engl. \& } \\
\text { Warb.; Impatiens lujai De } \\
\text { Wild.; Impatiens sultani } \\
\text { Hook.f.; Impatiens sultanii } \\
\text { Hook. f. (The Plant List, } \\
\text { 2013). }\end{array}$ & $\begin{array}{l}\text { East Africa (Kenya, } \\
\text { Tanzania, Malawi } \\
\text { and Mozambique) ( } \\
\text { CABI, 2020). }\end{array}$ & $\begin{array}{l}\text { Gardens, greenhouses, } \\
\text { clearings, roads, } \\
\text { secondary forests, } \\
\text { coastal forests, } \\
\text { riverbanks, wet } \\
\text { pastures, tropical and } \\
\text { subtropical forests ( } \\
\text { PFAF, 2020; Useful } \\
\text { Tropical Plants, 2016). }\end{array}$ & $\begin{array}{l}\text { Inflorescence usually } \\
\text { with two flowers, rarely } \\
\text { solitary. Variable } \\
\text { coloring between pink, } \\
\text { purple, violet, orange, } \\
\text { red and white (CABI, } \\
2020 \text { ). }\end{array}$ & $\begin{array}{l}0.3 \text { to } \\
0.8\end{array}$ & $\begin{array}{l}\text { Flowers ( } \\
\text { PFAF, } \\
\text { 2020). }\end{array}$ & $\begin{array}{l}\text { Enviromental } \\
\text { (Amenity), Folk } \\
\text { medicine, } \\
\text { Pharmaceutical and } \\
\text { Ornamental. Garnish in } \\
\text { salads or floated in } \\
\text { drinks (flowers) (CABI, } \\
\text { 2020). }\end{array}$ \\
\hline
\end{tabular}

and in North America. Szewczyk, 2018, on the other hand, states that the origin of these plants is not known for sure, but their first specimens were studied in Asia and East Africa.

Regarding the commercialization of these plants, it is believed that currently the species I. walleriana and Impatiens hawkeri W. Bull together move a market of 250 million dollars annually, in the United States alone (CABI, 2020b). Its uses are the most diverse, for example, the use of I. glandulifera for the production of honey (CABI, 2020c); the adoption of $I$. balsamina seed oils for the treatment of inflammation of the throat (CABI, 2020a).

According to the information collected, plants of this genus produced throughout the year, survive sandy and clayey soils, thrive in the presence or low incidence of light, have an affinity for humid environments, and can also show rapid growth (PFAF, 2020). In terms of size, they can vary from 0.4 to $2.5 \mathrm{~m}$ in height, are found in the most diverse territories around the world, present several applications in society, among them bioactive characteristics and edibility, these and other characteristics are presented according to the Table 1.

\subsection{Nutritional and chemical characterization}

Studies generally state that the nutritional content found in edible flowers does not differ from the nutrients found in other plant organs (Fernandes, Casal, Pereira, Saraiva, \& Ramalhosa, 2017). These, in turn, appear in different parts of the flowers, such as pollen, nectar and also in the petals according to. Fernandes et al. (2017) states that water is the main component found in flowers, which can vary between $70 \%$ and $95 \%$, followed by macronutrients such as carbohydrates, proteins and lipids, respectively. On the other hand, recent research on the chemical composition of flowers indicates the presence of high levels of micronutrients, such as vitamins, minerals, essential oils, mucilages and antioxidant substances (Stefaniak \& Grzeszczuk, 2019). However, due to the increased demand for consumption of edible flowers, more research is needed on the nutritional composition and bioactive compounds found in these plants (Cunningham, 2015), since literary studies are minimal regarding the nutrients present in this segment food, even for Impatiens L. flowers. However, some studies related to the presence of macro and micro nutrients in other organs of the genus, such as seeds 


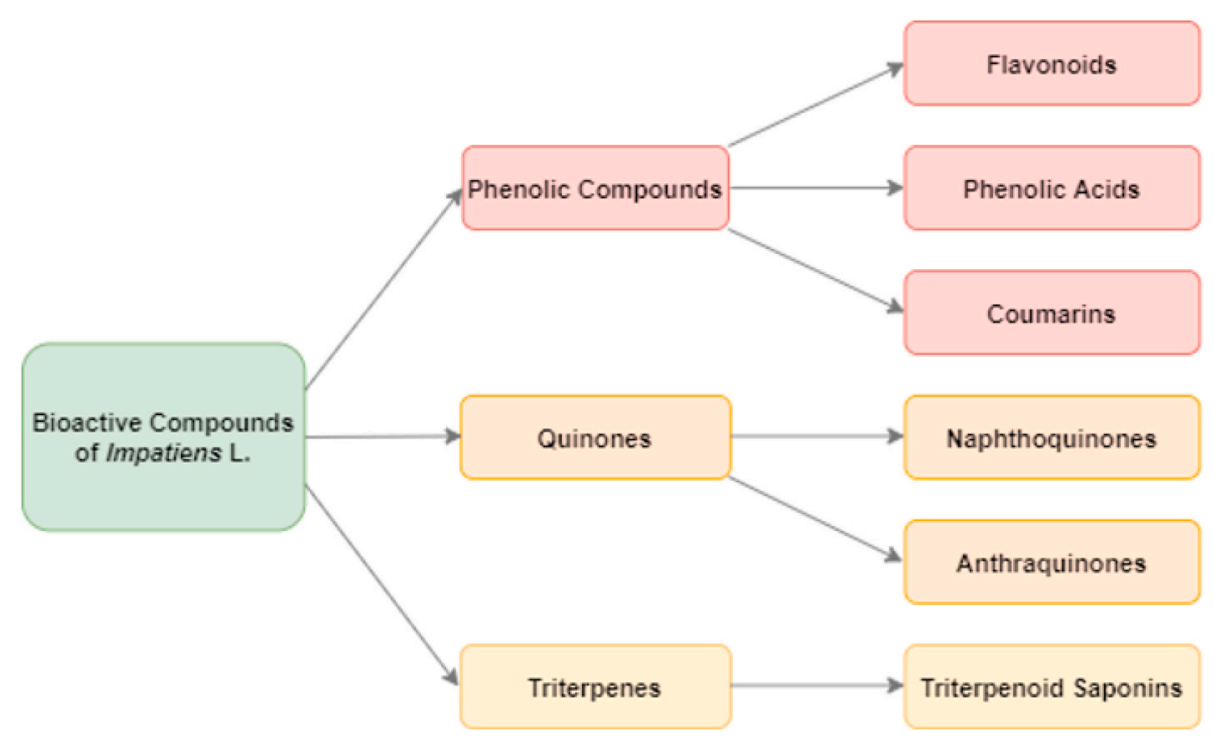

Fig. 1. Main compounds found in the genus Impatiens. (Authorship by the author).

and leaves are presented today.

Invasive plants, such as Impatiens, are relevant renewable resources of polysaccharides and phenolic compounds. These, in turn, can be assigned to the most diverse applications, as in cases of alternative medicine practices (Hromádková, Koštálová, Vrchotová, \& Ebringerová, 2014). A study regarding the chemical constitution of I. parviflora found the presence of several polysaccharide derivatives in its leaves (Hromádková et al., 2014). Among the results obtained, the kiln dried leaves showed high proportions of glucose, which were reduced after the application of pre-extraction techniques. In another way, traces of galactose, arabinose and glucose were discovered in the extractions with cold water, ethylenediamine tetraacetic acid (EDTA) and dimethylsulfoxide (DMSO). Meanwhile, components of monosaccharides, such as xylose, galactose, arabinose and glucose were present in the extractions made with $\mathrm{NaOH} 1 \%$ and $\mathrm{NaOH} 5 \%$ (Hromádková et al., 2014). Szewczyk, Heise, and Piwowarski (2018b), on the other hand, carried out a comparative study about the chemical composition and bioactivities existing in water-soluble polysaccharides, originating from four species of the genus Impatiens (I. parviflora, I. balsamina, I. glandulifera and Impatiens noli-tangere L.). The studied species showed similarity between their monosaccharide compositions, being identified arabinose, rhamnose, mannose, xylose, glucose, and galactose (which stood out as the major sugar among the samples) (Szewczyk, Heise, \& Piwowarski, 2018). However, these sugars differed in terms of proportion between species.

Meanwhile, Szewczyk, Bonikowski, MaciÄ...g-Krajewska, Abramek, and Bogucka-Kocka (2018c), observed the chemical composition of the lipophilic fractions present in the leaves, roots and seeds of the species I. glandulifera and I. noli-tangere. The first results obtained were related to the percentage of saturated fatty acids (12.2-27.2\%), monounsaturated (16.9-34.1\%) and polyunsaturated (40.3-55.8\%). As for the characterization, $\alpha$-linolenic, oleic and palmitic acids became predominant, as well as all samples presented constituents of $\omega-3$ and $\omega-6$ (Szewczyk, 2018). However, $\gamma$-linolenic acid was also found in large proportions in the roots (5.8\%) and leaves (7.9\%) of I. noli-tangere, while capric acid, was detected only in the roots and seeds of I. noli-tangere, and low amounts of arachidonic acid were present in the leaves and seeds of I. glandulifera (Szewczyk, 2018). Other reports state that $\alpha$-parinic acid is the main constituent of Impatiens seeds (Bagby, Smith, $\&$ Wolff, 1966). In turn, Fachun (2008) stated that I. balsamina seed oil is rich in unsaturated fatty acids (70.7\%), in which linoleic (16.5\%) and $\alpha$-linolenic (31.5\%) acids stand out. While Ortin and Evans (2013), determined the presence of fatty acids from Impatiens capensis Meerb seed oil and Impatiens pallida Nuttal, where percentages of palmitic, palmitoleic, stearic, oleic, linoleic, $\alpha$-linolenic and stearidonic acids were found.

There are still few studies that reveal the amounts of proteins present in the genus Impatiens. However, some specific studies report the existence of some derivatives, such as peptides and amino acids in the structural organs of these herbs. Through this perspective, Pal and Biswas (1994) discovered a high molecular weight protein from the pericarp of the I. balsamina pods. Tailor et al. (1997) identified a new family of small antimicrobial peptides present in I. balsamina seeds derived from a precursor protein. The identified peptides were designated as Ib-AMP1, Ib-AMP2, Ib-AMP3 and Ib-AMP4 and attracted their researchers because they are rich in cysteine and for presenting themselves as the smallest antimicrobial peptides derived from plants isolated until the time of their discovery. Patel, Osborn, Rees, and Thornton (1998), stated in his research that the protein variant Ib-AMP4, obtained from the seeds of I. balsamina, had greater antifungal activity than Ib-AMP1, particularly in media with high ionic strength. While Thevissen et al. (2005), reported that the peptides Ib-AMPs, from the seeds of I. balsamina, show potential in the fight against fungal infections and do not present hemolytic and toxic activity. Fan, Schäfer, Reichling \& Wink (2013), in turn, states that the bactericidal activity of the peptides from the seeds of the I. balsamina sample (Ib-AMP4) is fast and active against bacteria resistant to multiple drugs and that they can be combined with conventional antibiotics to treat microorganisms resistant.

\subsection{Bioactive compounds}

Food plays an important role in society, which goes beyond obtaining energy and providing nutrients, that is, many of them have different bioactive compounds, which contribute to human health and wellbeing. These compounds, in turn, act through the prevention and reduction of several pathologies, namely in the treatment of inflammation, in the regulation of immunity and in the delay of the oxidative stress process (Chugh \& Kamal-Eldin, 2020). In addition, other studies report that fruits and vegetables stand out for their high content in bioactive compounds, which are capable of preventing chronic and cardiovascular diseases (Gil, Amodio, \& Colelli, 2020, pp. 131-146). Zhang, Wen, Zhang, Duan, and Ma (2019) stated, that the active and natural ingredients are instruments of great value for human vitality, due to the biological effects and its wide application in the segment of functional foods and in the treatment of some diseases. While, Essien, Young, and Baroutian (2020), claims that bioactive compounds 
Table 2

Phytochemicals found in flowers of Impatiens species.

\begin{tabular}{|c|c|c|c|c|c|}
\hline $\begin{array}{l}\text { Compound } \\
\text { Family }\end{array}$ & Comoon Name & Compound Name & Extraction Methodology & Species & References \\
\hline \multirow[t]{7}{*}{$\begin{array}{l}\text { Phenolic } \\
\text { acids }\end{array}$} & Cinnamic acid & (E)-3-Phenylprop-2-enoic acid & $\begin{array}{l}\text { The extract was obtained from } 10 \mathrm{~g} \text { of sample, which were placed on } \\
\text { filter paper with chloroform and then extracted with } 80 \% \text { aqueous } \\
\text { methanol for a period of } 72 \mathrm{~h} \text {. }\end{array}$ & I. glandulifera & $\begin{array}{l}\text { Szewczyk and } \\
\text { Olech (2017) }\end{array}$ \\
\hline & Protocatechuic acid & 3,4-Dihydroxybenzoic acid & $\begin{array}{l}\text { The extract was obtained from white flowers of } I \text {. balsamina at room } \\
\text { temperature, containing } 80 \% \text { aqueous methanol as solvent. }\end{array}$ & I. balsamina & Kim et al. (2015) \\
\hline & Methyl paraben & Methyl 4-hydroxybenzoate & $\begin{array}{l}\text { The extract was obtained from white flowers of I. balsamina at room } \\
\text { temperature, containing } 80 \% \text { aqueous methanol as solvent. }\end{array}$ & I. balsamina & Kim et al. (2015) \\
\hline & 3-Hydroxycinnamic acid & (E)-3-(3-Hydroxyphenyl)prop-2-enoic acid). & $\begin{array}{l}\text { The extract was obtained from } 10 \mathrm{~g} \text { of sample, which were placed on } \\
\text { filter paper with chloroform and then extracted with } 80 \% \text { aqueous } \\
\text { methanol for a period of } 72 \mathrm{~h} \text {. }\end{array}$ & I. glandulifera & $\begin{array}{l}\text { Szewczyk and } \\
\text { Olech (2017) }\end{array}$ \\
\hline & Vanilic acid & 4-Hydroxy-3-methoxybenzoic acid & $\begin{array}{l}\text { The extract was obtained from white flowers of I. balsamina at room } \\
\text { temperature, containing } 80 \% \text { aqueous methanol as solvent. }\end{array}$ & I. balsamina & Kim et al. (2015) \\
\hline & m-Hydroxybenzoic acid & 3-Hydroxybenzoic acid & $\begin{array}{l}\text { The extract was obtained from } 10 \mathrm{~g} \text { of sample, which were placed on } \\
\text { filter paper with chloroform and then extracted with } 80 \% \text { aqueous } \\
\text { methanol for a period of } 72 \mathrm{~h} \text {. }\end{array}$ & I. glandulifera & $\begin{array}{l}\text { Szewczyk and } \\
\text { Olech (2017) }\end{array}$ \\
\hline & $p$-Hydroxybenzoic acid & 4-Hydroxybenzoic acid & $\begin{array}{l}\text { The extract was obtained from white flowers of } I \text {. balsamina at room } \\
\text { temperature, containing } 80 \% \text { aqueous methanol as solvent. }\end{array}$ & I. balsamina & Kim et al. (2015) \\
\hline \multirow[t]{2}{*}{$\begin{array}{l}\text { Nitrogen } \\
\text { compounds }\end{array}$} & Balsamitril & 2-[(3S)-3-hydroxy-2-oxo-1-benzofuran-3-yl]acetonitrile & $\begin{array}{l}\text { The extract was obtained from white flowers of I. balsamina at room } \\
\text { temperature, containing } 80 \% \text { aqueous methanol as solvent. }\end{array}$ & I. balsamina & Kim et al. (2015) \\
\hline & $\begin{array}{l}\text { Balsamitril-3-O- }-\mathrm{D}-\mathrm{-} \\
\text { glucoside }\end{array}$ & Balsamitril-3-O- $\beta$-D-glucoside & $\begin{array}{l}\text { The extract was obtained from white flowers of I. balsamina at room } \\
\text { temperature, containing } 80 \% \text { aqueous methanol as solvent. }\end{array}$ & I. balsamina & Kim et al. (2015) \\
\hline \multirow[t]{14}{*}{ Flavonoids } & Apigenin & 5,7-Dihydroxy-2-(4-hydroxyphenyl)chromen-4-one & $\begin{array}{l}\text { The extract was obtained from fresh matter of } I \text {. textori. The } \\
\text { extraction was carried out twice with } 35 \% \text { ethanol for } 1 \text { week at } \\
\text { room temperature. }\end{array}$ & I. textori & Ueda et al. (2003) \\
\hline & $\begin{array}{l}\text { Kaempferol 3,7- } \\
\text { diglucoside }\end{array}$ & $\begin{array}{l}\text { 5-Hydroxy-2-(4-hydroxyphenyl)-7-[(2S,4S,5S)-3,4,5-trihydroxy-6- } \\
\text { (hydroxymethyl)oxan-2-yl]oxychromen-4-one }\end{array}$ & $\begin{array}{l}\text { The extract was obtained from fresh matter of } I \text {. textori. The } \\
\text { extraction was carried out twice with } 35 \% \text { ethanol for } 1 \text { week at } \\
\text { room temperature. }\end{array}$ & I. textori & Ueda et al. (2003) \\
\hline & & & $\begin{array}{l}\text { The extracts were obtained from flowers of } I \text {. balsamina L., with the } \\
\text { addition of } 75 \% \text { ethanol }(3 \times 120 \mathrm{~L}, 2 \mathrm{~h} \text { each }) \text { at } 78^{\circ} \mathrm{C} \text {. }\end{array}$ & I. balsamina & $\begin{array}{l}\text { Li, Zhang, et al. } \\
\text { (2015) }\end{array}$ \\
\hline & $\begin{array}{l}\text { 6-Hydroxykaempferol 3- } \\
\text { Rutinoside -6-glucoside }\end{array}$ & $\begin{array}{l}\text { 5,7-di-hidroxi-2- (4-hidroxifenil)-3-[(2 } S, 3 R, 4 S, 5 S, 6 R \text { )-3,4,5-tri-hidroxi-6- } \\
\text { (hidroximetil) Oxan-2 -il] oxicromen-4-ona }\end{array}$ & $\begin{array}{l}\text { The extract was obtained from fresh matter of } I \text {. textori. The } \\
\text { extraction was carried out twice with } 35 \% \text { ethanol for } 1 \text { week at } \\
\text { room temperature. }\end{array}$ & I. textori & Ueda et al. (2003) \\
\hline & & & $\begin{array}{l}\text { The material was ground, later extracted with pure ethanol (99.9\%) } \\
\text { and maintained by maceration for } 24 \mathrm{~h} \text {. }\end{array}$ & I. glandulifera & Vieira et al. (2016) \\
\hline & & 3,5,7-Trihydroxy-2-(4-hydroxyphenyl)chromen-4-one & $\begin{array}{l}\text { The petals (or sepals) were extracted with } 1 \% \text { ethanolic } \\
\text { hydrochloric acid. }\end{array}$ & I. capensis & Clevenger (1958) \\
\hline & Kaempferol & & $\begin{array}{l}\text { The fresh material of I. balsamina was extracted at room } \\
\text { temperature, containing } 80 \% \text { aqueous methanol as solvent. }\end{array}$ & I. balsamina & Kim et al. (2017) \\
\hline & & & $\begin{array}{l}\text { The extract was obtained from fresh matter of } I \text {. textori. The } \\
\text { extraction was carried out twice with } 35 \% \text { ethanol for } 1 \text { week at } \\
\text { room temperature. }\end{array}$ & I. textori & Ueda et al. (2003) \\
\hline & & & $\begin{array}{l}\text { The material was ground, later extracted with pure ethanol (99.9\%) } \\
\text { and maintained by maceration for } 24 \mathrm{~h} \text {. }\end{array}$ & I. glandulifera & Vieira et al. (2016) \\
\hline & Balsamiside A, B, C and D & & $\begin{array}{l}\text { The fresh material of } I \text {. balsamina was extracted at room } \\
\text { temperature, containing } 80 \% \text { aqueous methanol as solvent. }\end{array}$ & I. balsamina & Kim et al. (2017) \\
\hline & & 5,7-Dihydroxy-2-(4-hydroxy-3-methoxyphenyl)chromen-4-one & $\begin{array}{l}\text { The extract was obtained from fresh matter of } I \text {. textori. The } \\
\text { extraction was carried out twice with } 35 \% \text { ethanol for } 1 \text { week at } \\
\text { room temperature. }\end{array}$ & I. textori & Ueda et al. (2003) \\
\hline & & $\begin{array}{l}\text { 2-(3,4-dihydroxyphenyl)-5-hydroxy-7-[( } 2 S, 3 R, 4 R, 5 S, 6 R) \text {-3,4,5-trihydroxy-6- } \\
\text { (hydroxymethyl)oxan-2-yl]oxy-2,3-dihydrochromen-4-one }\end{array}$ & $\begin{array}{l}\text { The material was ground, later extracted with pure ethanol (99.9\%) } \\
\text { and maintained by maceration for } 24 \mathrm{~h} \text {. }\end{array}$ & I. glandulifera & Vieira et al. (2016) \\
\hline & & $\begin{array}{l}\text { 2-(3,4-dihydroxyphenyl)-5,7-dihydroxy-3-[(2S,3R,4S,5R,6R)-3,4,5-trihydroxy- } \\
\text { 6-(hydroxymethyl)oxan-2-yl] oxychromen-4-one }\end{array}$ & $\begin{array}{l}\text { The material was ground, later extracted with pure ethanol (99.9\%) } \\
\text { and maintained by maceration for } 24 \mathrm{~h} \text {. }\end{array}$ & I. glandulifera & Vieira et al. (2016) \\
\hline & Luteolin & 2-(3,4-dihydroxyphenyl)-5,7-dihydroxychromen-4-one & & I. textori & Ueda et al. (2003) \\
\hline
\end{tabular}

\section{Kaempferol 3,7-}

6-Hydroxykaempferol 3-

\section{3,5,7-Trihydroxy-2-(4-hydroxyphenyl)chromen-4-one}

The extract was obtained from $10 \mathrm{~g}$ of sample, which were placed on filter paper with chloroform and then extracted with $80 \%$ aqueous

temperature, containing $80 \%$ aqueous methanol as solvent.

The

filter paper with chloroform and then extracted with $80 \%$ aqueous

temperature, containing $80 \%$ aqueous methanol as solvent.

he extract was obtained from $10 \mathrm{~g}$ of sample, which were placed on methenol for a period of $72 \mathrm{~h}$.

hite flowers of $I$ balsamina at room

ined from white flowers of $I$ balsamina at roon merature, containing $80 \%$ aqueous methanol as solvent.

, cos obtained from fresh matter of the

addition of $75 \%$ ethanol ( $3 \times 120 \mathrm{~L}, 2 \mathrm{~h}$ each) at $78^{\circ} \mathrm{C}$.

was obtained from fresh matter of 1 .

(othe were extracted with $1 \%$ ethanolic

(hydroxymethyl)oxan-2-yl] oxy-2,3-dihydrochromen-4-one

6-(hydroxymethyl)oxan-2-ylloxychromen-4-o

(continued on next page) 


\begin{tabular}{|c|c|c|c|c|c|}
\hline $\begin{array}{l}\text { Compound } \\
\text { Family }\end{array}$ & Comoon Name & Compound Name & Extraction Methodology & Species & References \\
\hline & & & $\begin{array}{l}\text { The extract was obtained from fresh matter of I. textori. The } \\
\text { extraction was carried out twice with } 35 \% \text { ethanol for } 1 \text { week at } \\
\text { room temperature. }\end{array}$ & & \\
\hline & Myricetin & 3,5,7-Trihydroxy-2-(3,4,5-trihydroxyphenyl)chromen-4-one & $\begin{array}{l}\text { The extracts were obtained from flowers of } I \text {. balsamina } L \text {., with the } \\
\text { addition of } 75 \% \text { ethanol }(3 \times 120 \mathrm{~L}, 2 \mathrm{~h} \text { each }) \text { at } 78^{\circ} \mathrm{C} \text {. }\end{array}$ & I. balsamina & $\begin{array}{l}\text { Li, Zhang, et al. } \\
\text { (2015) }\end{array}$ \\
\hline & Myricetin 3-galactoside & $\begin{array}{l}\text { 5,7-Dihydroxy-3-[(2S,3R,4S,5R,6R)-3,4,5-trihydroxy-6-(hydroxymethyl)oxan- } \\
\text { 2-yl]oxy-2-(3,4,5-trihydroxyphenyl)chromen-4-one }\end{array}$ & $\begin{array}{l}\text { The material was ground, later extracted with pure ethanol (99.9\%) } \\
\text { and maintained by maceration for } 24 \mathrm{~h} \text {. }\end{array}$ & I. glandulifera & Vieira et al. (2016) \\
\hline & Nicotiflorin & $\begin{array}{l}\text { 5,7-Dihydroxy-2-(4-hydroxyphenyl)-3-[(2S,3R,4S,5S,6R)-3,4,5-trihydroxy-6- } \\
\text { [[(2R,3R,4R,5R,6S)-3,4,5-trihydroxy-6-methyloxan-2-yl] oxymethyl] oxan-2-yl] } \\
\text { oxychromen-4-one }\end{array}$ & $\begin{array}{l}\text { The extracts were obtained from flowers of I. balsamina L., with the } \\
\text { addition of } 75 \% \text { ethanol }\left(3 \times 120 \mathrm{~L}, 2 \mathrm{~h} \text { each) at } 78^{\circ} \mathrm{C} \text {. }\right.\end{array}$ & I. balsamina & $\begin{array}{l}\text { Li, Zhang, et al. } \\
\text { (2015) }\end{array}$ \\
\hline & Isoquercitrin & $\begin{array}{l}\text { 2-(3,4-Dihydroxyphenyl)-5,7-dihydroxy-3-[(2S,3R,4S,5S,6R)-3,4,5-trihydroxy- } \\
\text { 6-(hydroxymethyl)oxan-2-yl] oxychromen-4-one }\end{array}$ & $\begin{array}{l}\text { The extract was obtained from fresh matter of } I \text {. textori. The } \\
\text { extraction was carried out twice with } 35 \% \text { ethanol for } 1 \text { week at } \\
\text { room temperature. }\end{array}$ & I. textori & Ueda et al. (2003) \\
\hline & & & $\begin{array}{l}\text { The fresh material of } I . \text { balsamina was extracted at room } \\
\text { temperature, containing } 80 \% \text { aqueous methanol as solvent. }\end{array}$ & I. balsamina & Kim et al. (2017) \\
\hline & & Derivatives of 3,5,7-trihydroxy-2-(4-hydroxyphenyl) chromen-4-one & $\begin{array}{l}\text { The fresh material of } I \text {. balsamina was extracted at room } \\
\text { temperature, containing } 80 \% \text { aqueous methanol as solvent. }\end{array}$ & I. balsamina & Kim et al. (2017) \\
\hline & & & $\begin{array}{l}\text { The extract was obtained from fresh matter of } I \text {. textori. The } \\
\text { extraction was carried out twice with } 35 \% \text { ethanol for } 1 \text { week at } \\
\text { room temperature. }\end{array}$ & I. textori & Ueda et al. (2003) \\
\hline & & & $\begin{array}{l}\text { The fresh material of } I \text {. balsamina was extracted at room } \\
\text { temperature, containing } 80 \% \text { aqueous methanol as solvent. }\end{array}$ & I. glandulifera & Kim et al. (2017) \\
\hline & Quercetin & 2-(3,4-Dihydroxyphenyl)-3,5,7-trihydroxychromen-4-one & $\begin{array}{l}\text { The fresh material of } I \text {. balsamina was extracted at room } \\
\text { temperature, containing } 80 \% \text { aqueous methanol as solvent. }\end{array}$ & I. balsamina & Kim et al. (2017) \\
\hline & & & $\begin{array}{l}\text { The extract was obtained from fresh matter of } I \text {. textori. The } \\
\text { extraction was carried out twice with } 35 \% \text { ethanol for } 1 \text { week at } \\
\text { room temperature. }\end{array}$ & I. textori & Ueda et al. (2003) \\
\hline & & & $\begin{array}{l}\text { The material was ground, later extracted with pure ethanol }(99.9 \%) \\
\text { and maintained by maceration for } 24 \mathrm{~h} \text {. }\end{array}$ & I. glandulifera & Vieira et al. (2016) \\
\hline & $\begin{array}{l}\text { Quercetin 3-O- } \\
\text { Malonylglucoside }\end{array}$ & $\begin{array}{l}\text { 3-[[(2R,3S,4S,5R,6S)-6-[2-(3,4-dihydroxyphenyl)-5,7-dihydroxy-4- } \\
\text { oxochromen-3-yl]oxy-3,4,5-trihydroxyoxan-2-yl]methoxy]-3-oxopropanoic } \\
\text { acid }\end{array}$ & $\begin{array}{l}\text { The material was ground, later extracted with pure ethanol (99.9\%) } \\
\text { and maintained by maceration for } 24 \mathrm{~h} \text {. }\end{array}$ & I. glandulifera & Vieira et al. (2016) \\
\hline & & $\begin{array}{l}\text { 2-(3,4-dihydroxyphenyl)-5,7-dihydroxy-3-[(2S,3R,4S,5S,6R)-3,4,5-trihydroxy- } \\
\text { 6-[[(2R,3R,4R,5R,6S)-3,4,5-trihydroxy-6-methyloxan-2-yl] oxymethyl] oxan-2- } \\
\text { yl] oxychromen-4-one }\end{array}$ & $\begin{array}{l}\text { The extracts were obtained from flowers of } I \text {. balsamina } L \text {., with the } \\
\text { addition of } 75 \% \text { ethanol }(3 \times 120 \mathrm{~L}, 2 \mathrm{~h} \text { each }) \text { at } 78^{\circ} \mathrm{C} \text {. }\end{array}$ & I. balsamina & $\begin{array}{l}\text { Li, Zhang, et al. } \\
\text { (2015) }\end{array}$ \\
\hline \multirow[t]{3}{*}{ Quinones } & $\begin{array}{l}\text { 2-Methoxy-1,4- } \\
\text { Naphthoquinone }\end{array}$ & 2-Methoxynaphthalene-1,4-dione & $\begin{array}{l}\text { The extract was obtained from white flowers of I. balsamina at room } \\
\text { temperature, containing } 80 \% \text { aqueous methanol as solvent. }\end{array}$ & I. balsamina & Kim et al. (2015) \\
\hline & & & $\begin{array}{l}\text { The plant material was coarsely macerated and left to infuse in } \\
\text { cyclohexane for } 24 \mathrm{~h} \text {. The mixture was decanted and filtered, } \\
\text { removing remnants of plant material, and then dried over sodium } \\
\text { sulfate. }\end{array}$ & I. glandulifera & $\begin{array}{l}\text { Ortin and Evans } \\
\text { (2013) }\end{array}$ \\
\hline & & Balsaminone $\mathrm{B}, \mathrm{D}$ and $\mathrm{E}$ & $\begin{array}{l}\text { The dried flowers of I. balsamina were extracted with } 75 \% \text { ethanol } \\
\text { under reflux at } 78^{\circ} \mathrm{C} \text {. The extract was concentrated in vacuo and } \\
\text { suspended in water, then divided with petroleum ether, } \\
\text { dichloromethane, ethyl acetate and n-butanol. }\end{array}$ & I. balsamina & $\begin{array}{l}\text { Li, Guo, et al. } \\
\text { (2015) }\end{array}$ \\
\hline Saponins & & Balsaminside A, B, C and D & $\begin{array}{l}\text { I. balsamina flowers were extracted with } 75 \% \text { ethanol under reflux } \\
\text { at } 78{ }^{\circ} \mathrm{C} \text { three times. The extract was concentrated in vacuo and } \\
\text { suspended in water, then divided with petroleum ether, } \\
\text { dichloromethane, ethyl acetate and n-butanol successively. }\end{array}$ & I. balsamina & Li et al. (2017) \\
\hline \multirow[t]{2}{*}{$\begin{array}{l}\text { Other } \\
\text { compounds }\end{array}$} & Luteolin epoxide & $\begin{array}{l}(1 R, 3 S, 6 S)-6-[(1 E, 3 E, 5 E, 7 E, 9 E, 11 E, 13 E, 15 E, 17 E)-18 \text {-[(1R,4R)-4-hydroxy-2,6,6- } \\
\text { trimethylcyclohex-2-en-1-yl]-3,7,12,16-tetramethyloctadeca- } \\
\text { 1,3,5,7,9,11,13,15,17-nonaenyl]-1,5,5-trimethyl-7-oxabicyclo[4.1.0]heptan-3- } \\
\text { ol }\end{array}$ & Petal pigments and open flower sepals were extracted. & I. noli-tangere & $\begin{array}{l}\text { Wrischer, Ljubesic, } \\
\text { Prebeg, and e } \\
\text { Magnus (1999) }\end{array}$ \\
\hline & Tyrosol & 4-(2-Hydroxyethyl)phenol & & I. balsamina & Kim et al. (2015) \\
\hline
\end{tabular}

Myricetin

5,7-Dihydroxy-3-[(2S,3R,4S,5R,6R)-3,4,5-trihydroxy-6-(hydroxymethyl)oxan-yl] oxy-2-(3,4,5-trihydroxyphenyl)chromen-4-one oxychromen-4-on

-(3,4-Dihydroxyphenyl)-5,7-dihydroxy-3-[(2S,3R,4S,5S,6R)-3,4,5-trihydrox -(hydroxymethyl)oxan-2-yl] oxychromen-4-one

Derivatives of 3,5,7-trihydroxy-2-(4-hydroxyphenyl) chromen-4-one

xy]-3-oxopropanoi

2-(3,4-dihydroxyphenyl)-5,7-dihydroxy-3-[(2S,3R,4S,5S,6R)-3,4,5-trihydroxy6-[(2R,3R,4R,5R,6S)-3,4,5-trihydroxy-6-methyloxan-2-yl]oxymethyl $0 x a n-2-$ yl]oxychromen-4-one

2-Methoxynaphthalene-1,4-dione

\section{Balsaminone B, D and $\mathrm{E}$}


Table 2 (continued)

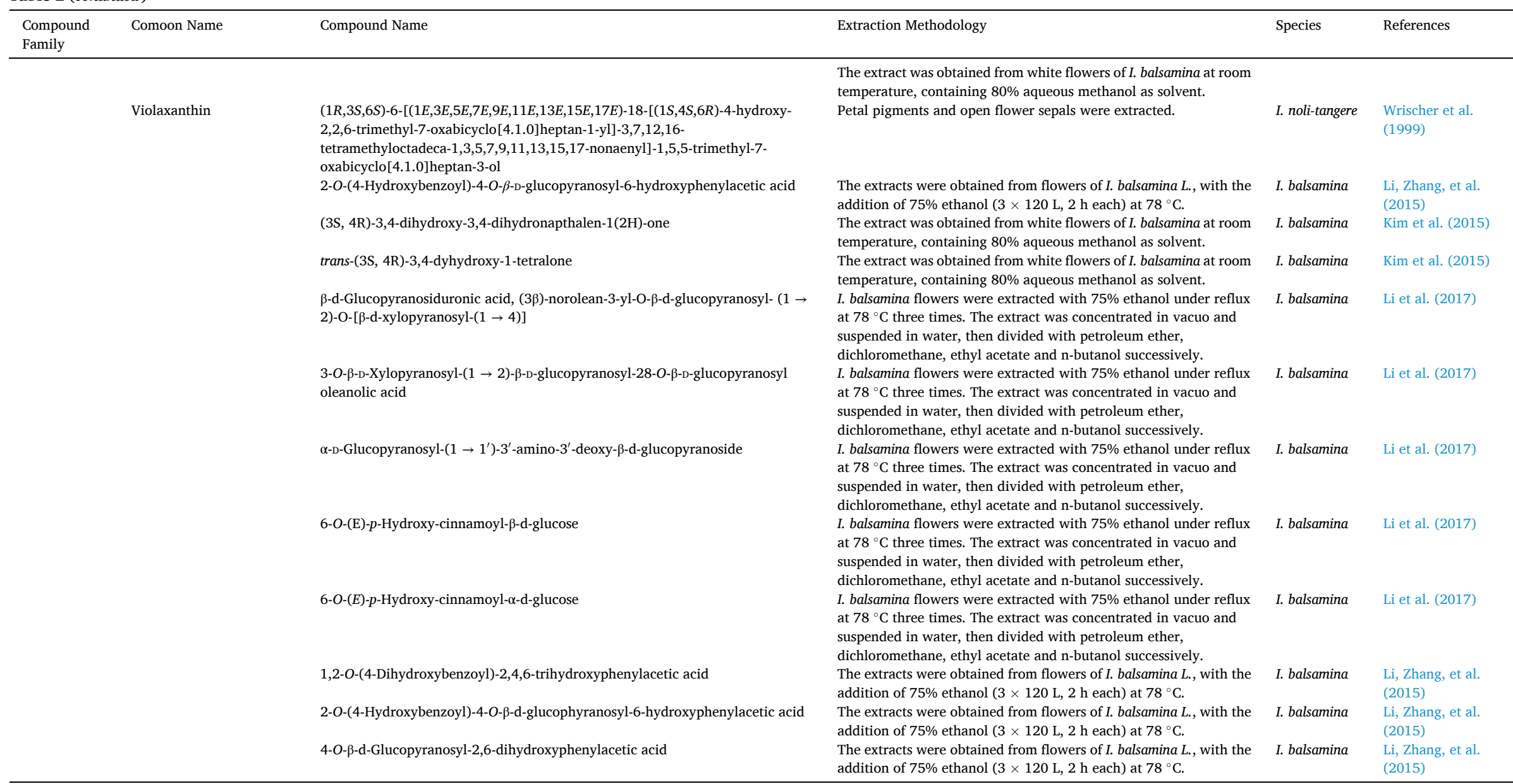


originating from plants, algae, food and by-products are able to interact with the components of living tissues, in order to provide the most diverse effects.

These compounds are also present in edible flowers. As an example, we can mention some compounds found in greater abundance, such as protocatechuic acid in Hibiscus sabdariffa L. that play an antioxidant role, luteolin in Lonicera japonica Thunb. that act as anti-inflammatories and quercetin in water lily that can prevent obesity (Lu, Li, \& Yin, 2016). Also, Pires, Dias, Barros, and Ferreira (2017), reinforce that edible flowers are responsible for providing many health benefits to those who consume them, due to the presence of bioactive molecules, which posse biological effects.

Phytochemical research carried out with examples of the genus Impatiens, affirm the presence of numbers of bioactive molecules in its composition. Among the various bioactive compounds present in the genus Impatiens, naphthoquinone, coumarin, phenolic acid, flavonoids, anthocyanins, steroids and peptides are the main ones (Li et al., 2017). A brief summary of the main compounds present in the genus can be found in Fig. 1.

Studies regarding the bioactive compounds present in the genus Impatiens stand out, in addition to phenolic compounds, as well as the components present, such as quinones and triterpenes that perform various actions related to human health. However, a current study indicates the presence of approximately 300 distinct phytochemicals in more than twenty-seven species studied by the genus Impatiens (Szewczyk, 2018). Some of the main compounds present in Impatiens flowers can be seen according to Table 2.

Phenolic compounds make up one of the main groups of nonessential food components synthesized by the secondary metabolism of plants and have a multitude of substances within their class (Rodríguez-Pérez, Segura-Carretero \& del Mar Contreras, 2019). They are capable of conferring several benefits to human health, especially in the fight against chronic diseases, such as diabetes and hypertension (Fraga, Croft, Kennedy \& Tomás-Barberán, 2019). Over the years, this class of compounds have traditionally been used as food coloring, in addition to some studies showing an inverse relationship between the intake of foods rich in phenolic compounds, and the occurrence of several cardiovascular diseases (Rodríguez-Pérez, Segura-Carretero \& del Mar Contreras, 2019). Therefore, these compounds are considered valuable for obtaining functional ingredients.

Over time, the presence of many of these compounds have been confirmed in the various parts that make up the plants of the genus Impatiens. The family of flavonoids consists of more than 9000 specimens of individual compounds that are considered potential antioxidants (Hernández, Alegre, Van Breusegem \& Munné-Bosch, 2009).

In a study carried out in Poland, concerning the phenolic composition of aerial parts of I. glandulfera, the presence of eight distinct flavonoids, two phenolic acids and the compound 2-methoxynaphthalene1,4-dione (Szewczyk, Sezai Cicek, Zidorn, \& Granica, 2019). In a subsequent study, made from Impatiens hypophylla Makino, seven flavonoids and a coumarin were also found (Tsushiro, Kurizaki, Watanabe, \& Devkota, 2019). Meanwhile, tetrahydronaphthalene was isolated for the first time on stems of I. balsamina, along with eleven other distinct compounds by researchers in Korea (Kim, Lee, Subedi, Kim, \& Lee, 2019).

Szewczyk, Zidorn, Biernasiuk, Komsta and Granica (2016a), stated in their study, that the extracts (methanol/acetone/water (3/1/1, v/v/v; 3 $\times 50 \mathrm{ml}$ ) of I. balfourii Hook.f. (1903)., I. glandulífera and I. parviflora, have significant amounts of phenolic acids and flavonoids responsible for a multidirectional bioactive activity, as they are capable of presenting antioxidant characteristics and antimicrobial at the same time. In addition to this aspect, Clevenger (1958), found that a subclass of flavonoids, flavonois are constituents of the most diverse parts of I. balsamina, so that kaempferol and myricetin present mainly in petals and sepals, while quercetin was only present in sepals (Fukumoto, Ishiguro, Murashima, Yamaki, \& Isoi, 1994; Hua, Peng, Chia, Goh, \& Tan,
2001; Lim, Kim, \& Seo, 2007). Chua (2016), stated that flavonoids are the major compounds in leaf extracts (methanol) of I. balsamina. Kim et al. (2017), attested the presence of four biflavonoid glycosides (balasamisides A, B, C and D) in white petals of I. balsamina. Vieira, Winterhalter, and Jerz (2016), composed the first report about the composition of flavonoids in the species of I. glanduliferous, in which dihydromyricetin, eriodictiol-7-O-glucoside, kaempferol-3-O-glucoside and kaempferol-3-O-6"-malonyl-glucoside were isolated. Hasan and Tahir (2005), characterized nine flavone glycosides from the leaves of I. bicolor Royle, three of which were new discoveries.

They are known in the scientific community for promoting the health of some fruits and vegetables, in addition to giving unique flavors to foods and affecting the growth and reproduction of plants (Espín \& Tomas-Barberan, 2001). Due to these peculiarities, some researchers strive to quantify and identify this class of acids in the most diverse plants, including Impatiens. Szewczyk and Olech (2017) for example, applied several methodologies of solid-liquid extraction with methanol (80:20) in specimens of I. glandulifera in order to obtain ultrasound as the best optimized method of extraction. Later on the same authors, found the presence of thirteen phenolic acids (gallic acid; protocatechuic acid; gentisic acid; 4-hydroxybenzoic acid; vanilic acid; trans-caffeic acid; syringic acid; trans-p-coumaric acid; cis-p-coumaric acid; trans-ferulic acid; salicylic acid; cis-ferulic acid; 3-hydroxycinnamic acid) from four other species (I. balsamina, I. noli-tangere, I. parviflora and I. walleriana), in which the leaves of the species I. glandulifera and I. noli-tangere highlighted themselves as the organs with the greatest amount of these compounds (Szewczyk \& Olech, 2017). In a more remote study Mansell and Kemerer (1970), observed the existence of hydroxycinnamic acid derivatives in the white, red and purple petals of I. balsamina. Among the discoveries, $p$-karmaric acid was mostly found in the red petals, while ferulic acid showed a higher concentration in the purple genotype. Bohm and Towers (1962), investigated the presence of ten distinct phenolic acids (gentisic acid, $p$-hydroxybenzoic acid, protocatechuic acid, salicylic acid, syringic acid, vanilic acid, caffeic acid, p-coumaric acid, ferulic acid, synaptic acid), in ten species of Impatiens.

Another class of compounds widely found in Impatiens are coumarins. Which are defined as groupings of benzene rings and pyrones, responsible for conferring a therapeutic potential, especially in the prevention of some cancers (Thakur, Singla, \& Jaitak, 2015). The first reports about coumarin isolations in Impatiens are dated 1964 and in this study, the leaves of fourteen species of the genus showed traces of scopelithin (Szewczyk, Bonikowski, et al., 2018c). In addition, the presence of isofraxidine and scopelithin from I. balsamina roots has been reported (Panjchayupakaranant, Noguchi, De-Eknamkul, \& Sankawa, 1995). Chua (2016), in turn, found the presence of scopoletin diacyldipentoside in the stems and leaves of I. balsamina.

\subsection{Natural pigments}

Colored additives or food colors are chemicals, pigments or other coloring substances that can add colour to foods, beverages or non-food applications (including pharmaceuticals) and classified as natural, semisynthetic and synthetic (Amchova, Kotolova, \& Ruda-Kucerova, 2015). The natural pigments are extracted from food or edible natural materials, through physical-chemical processes, being used in the most diverse forms (Coultate \& Blackburn, 2018). Semi-synthetic colorants are similar to natural colorant, but their methods of synthesis are carried out by chemical processes, whereas synthetic colour are produced by chemical processes, however they are not found in nature (Amchova et al., 2015).

Nowadays, the food industry is raising several questions about the health risks caused by the inappropriate use of synthetic colour in the composition of industrialized foods, since the possible exaggeration of the use of these substances can confer risk to human health (Albuquerque et al., 2017; Anastácio, Oliveira, Delmaschio, Antunes \& Checker, 2016; Jimenez-Gonzalez et al., 2018). 


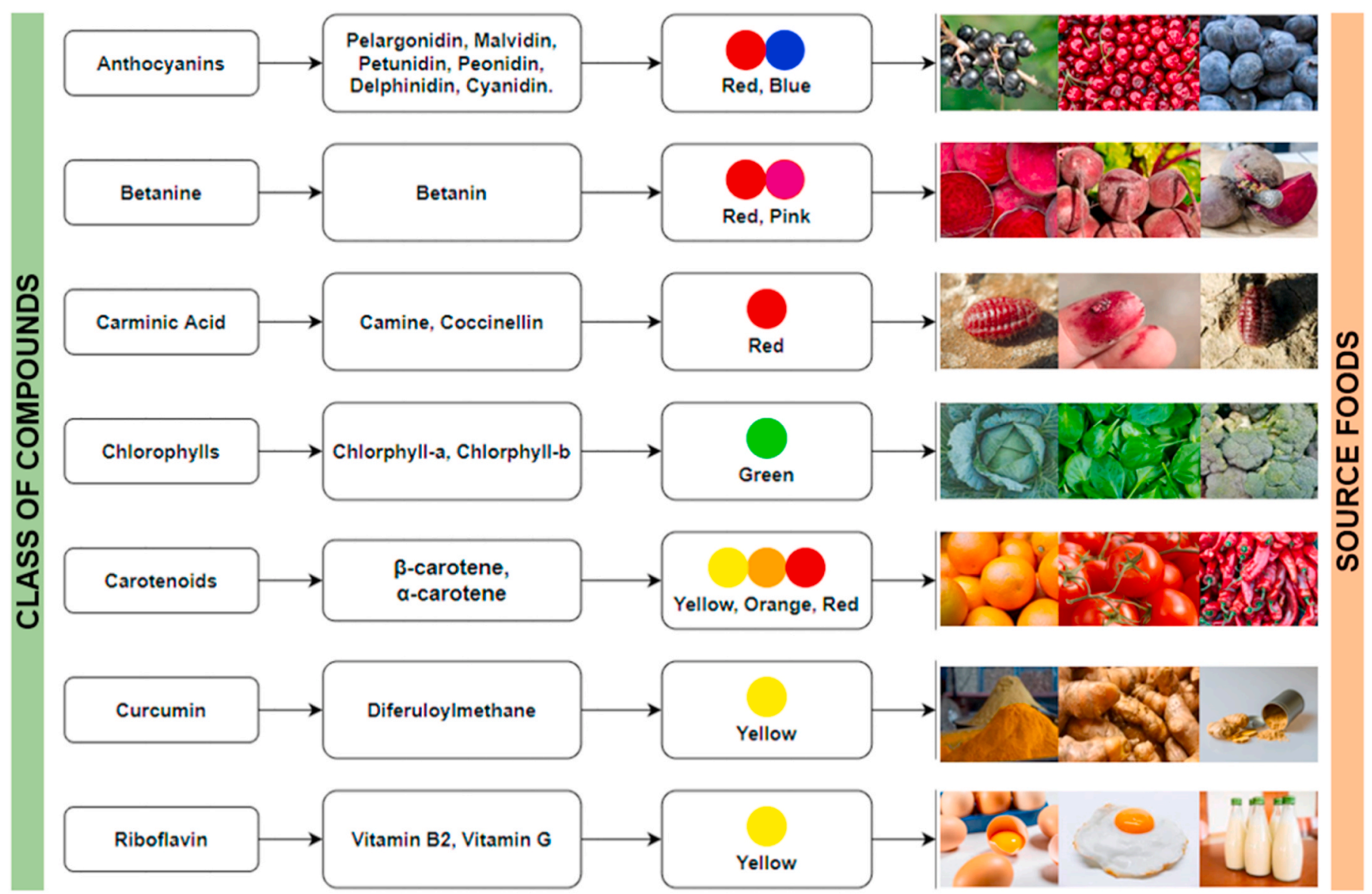

Fig. 2. Classification of natural colorants. (Authorship by the author).

On the other hand, natural colorants attract several scholars, due to the existence of functional and nutraceutical properties in their compositions (López et al., 2018; Rodriguez-Amaya, 2016; Rowles III \& Erdman, 2020). In addition, the segments of natural colour consist of numerous substances, but among them, the anthocyanins, betalains, carminic acid, chlorophyll, carotenoids, curcumins and riboflavin stand out as some of the most important (Schiozer \& Barata, 2013), as shown in Fig. 2.

As for a more specific definition, it can be said that anthocyanins, are flavonoids originating from the secondary metabolism of plants, have solubility in water, attract attention by colour, which varies from red to blue and are generally found in various plant organs, such as fruits, roots, leaves and flowers (López et al., 2018; Santos-Buelga \& González-Paramás, 2019). In addition, studies report the existence of twenty-two main anthocyanin compounds, in which only six of them are relevant to the food industry, namely: cyanidin, delfinidine, malvidin, pelargonidine, peonidine and petunidine (Santos-Buelga \& González-Paramás, 2019; Schiozer \& Barata, 2013).

Currently, anthocyanin compounds have aroused interest not only for the scientific community (Benvenuti, Bortolotti, \& Maggini, 2016; Khoo, Azlan, Tang, \& Lim, 2017), but also for the industrial sector, due to their bioactive properties and their advantages as food colors (Bleve et al., 2008; Puértolas, Cregenzán, Luengo, Álvarez, \& Raso, 2013), However, obtaining raw chemical substances and stable dyes are the biggest current challenges, when compared to the best conservation conditions by synthetic chemical substances (Anastácio, Oliveira, Delmaschio, Antunes \& Checker, 2016; Schiozer \& Barata, 2013; Tarone, Cazarin, \& Junior, 2020).

In the universe of edible flowers, anthocyanins are compounds that are of remarkable importance in terms of colour assignment (Goto \&
Kondo, 1991; Lawrence, Price, Robinson \& Robison, 1939). Some studies have stated the presence of these flavonoids in the flowers of Lilium spp. (Yamagishi, Uchiyama, \& Handa, 2018), Hibiscus sabdariffa (Grajeda-Iglesias, Salas, Barouh, Barea and Figueroa-Espinoza, 2017), Ramat chrysanthemum morifolium (Liu, Xiang, Yin, Grierson \& Chen, 2015) and Paeonia suffruticosa (Zhang et al., 2014), in addition to being present in the genus Impatiens (Aras, Cevahir, Yentür, Eryılmaz, Sarsağ et al., 2007; Klein \& Hagen, 1961).

Studies related to the presence of anthocyanin compounds in the genus Impatiens are scarce and need to be updated. Because its flowers have great attractiveness in terms of coloring molecules, being a possible natural source, in addition to conferring health benefits due to the bioactive properties of these compounds. However, Aras et al. (2007), investigated the location of anthocyanins in different parts of I. balsamina, stating that the pigment production capacity of this species is directly related to everyday factors, such as environmental and nutritional conditions.

Initial studies carried out with nineteen species of the genus Impatiens reported the predominance of cyanidin widely distributed in flower petals and sepals, while malvidin was the most common pigment in petals (Clevenger, 1971). In addition, it was also stated that the petals had more elaborate combinations of pigments when compared to the stems that have fewer complex pigmentations (Clevenger, 1971). Other studies have indicated that the anthocyanin compounds most present in the genus Impatiens are pelargonidin and peonidine, isolated a priori in flowers of I. balsamina, and that other anthocyanins derived from the classes of malvidins, delfinidine and cyanidin can also be found in specimens of the gender (Szewczyk, 2018). Leucoanthocyanidins, on the other hand, present themselves as the main responsible for the attribution of the reddish coloration of the roots and mature roots in several 
Table 3

Anthocyanic compounds found in several species of the genus Impatiens.

\begin{tabular}{|c|c|c|c|c|c|}
\hline Compound Name & $\begin{array}{l}\text { Molecular } \\
\text { Formula }\end{array}$ & IUPAC Name & Extraction Methodology & Species & References \\
\hline \multirow[t]{4}{*}{ Cyanidin } & $\mathrm{C}_{15} \mathrm{H}_{11} \mathrm{O}_{6}+$ & 2-(3,4-dihydroxyphenyl)chromenylium-3,5,7-triol & $\begin{array}{l}\text { Extraction at room temperature } \\
\text { with } 1 \% \text { hydrochloric acid in } 95 \% \\
\text { ethyl alcohol }(\mathrm{v} / \mathrm{v}) \text {. }\end{array}$ & I. balsamina & $\begin{array}{l}\text { Klein and Hagen } \\
\text { (1961) }\end{array}$ \\
\hline & & & $\begin{array}{l}\text { Extraction with } 50 \% \text { ethanol and } \\
\text { then introduced in a sonication } \\
\text { bath, at a frequency of } 35 \mathrm{kHz} \text {. }\end{array}$ & I. noli-tangere & $\begin{array}{l}\text { Paun et al. } \\
(2018)\end{array}$ \\
\hline & & & $\begin{array}{l}\text { Anthocyanins were extracted from } \\
\text { fresh material (flowers, capsules, } \\
\text { pollen and sepals) with methanolic } \\
\text { hydrochloric acid ( } 1 \% \text { solution). }\end{array}$ & I. holstii & $\begin{array}{l}\text { Klozová \& } \\
\text { Rokosová, } 1961\end{array}$ \\
\hline & & & $\begin{array}{l}\text { The petal extract was obtained } \\
\text { using } 1 \% \text { ethanolic hydrochloric } \\
\text { acid. }\end{array}$ & I. capensis & $\begin{array}{l}\text { Clevenger } \\
(1958)\end{array}$ \\
\hline \multirow[t]{2}{*}{ Cyanidin 3-O-glucoside } & $\mathrm{C}_{21} \mathrm{H}_{21} \mathrm{O}_{11}+$ & $\begin{array}{l}\text { (2S,3R,4S,5S,6R)-2-[2-(3,4-dihydroxyphenyl)-5,7- } \\
\text { dihydroxychromenylium-3-yl]oxy-6- } \\
\text { (hydroxymethyl)oxane-3,4,5-trio }\end{array}$ & $\begin{array}{l}\text { Extraction with } 70 \% \text { ethanol } \\
\text { containing } 0.4 \% \text { hydrochloric acid } \\
(\mathrm{v} / \mathrm{v}) \text {. }\end{array}$ & I. balsamina & Hagen, 1966 \\
\hline & & & $\begin{array}{l}\text { Extraction with methanol with } 1 \% \\
\text { hydrochloric acid. }\end{array}$ & I. platypetala & $\begin{array}{l}\text { Thakur and } \\
\text { Nozzolillo. } \\
\text { (1978) }\end{array}$ \\
\hline Delphinidin & $\mathrm{C}_{15} \mathrm{H}_{11} \mathrm{C}_{1} \mathrm{O}_{7}$ & $\begin{array}{l}\text { 2-(3,4,5-trihydroxyphenyl)chromenylium-3,5,7- } \\
\text { triol; chloride }\end{array}$ & $\begin{array}{l}\text { Extraction at room temperature } \\
\text { with } 1 \% \text { hydrochloric acid in } 95 \% \\
\text { ethyl alcohol }(\mathrm{v} / \mathrm{v}) \text {. }\end{array}$ & I. balsamina & $\begin{array}{l}\text { Alston and } \\
\text { Hagen (1958) }\end{array}$ \\
\hline \multirow[t]{3}{*}{ Malvidin } & $\mathrm{C}_{17} \mathrm{H}_{15} \mathrm{O}_{7}+$ & $\begin{array}{l}\text { 2-(4-hydroxy-3,5-dimethoxyphenyl)chromenylium- } \\
\text { 3,5,7-triol }\end{array}$ & $\begin{array}{l}\text { Anthocins were extracted from } \\
\text { fresh material (flowers, capsules, } \\
\text { pollen and sepals) with methanolic } \\
\text { hydrochloric acid ( } 1 \% \text { solution). }\end{array}$ & I.hostii & $\begin{array}{l}\text { Klozová \& } \\
\text { Rokosová, } 1961\end{array}$ \\
\hline & & & $\begin{array}{l}\text { Extraction with } 50 \% \text { ethanol and } \\
\text { then introduced in a sonication } \\
\text { bath, at a frequency of } 35 \mathrm{kHz} \text {. }\end{array}$ & I.noli-tangere & $\begin{array}{l}\text { Paun et al. } \\
\text { (2018) }\end{array}$ \\
\hline & & & $\begin{array}{l}\text { The plant parts were extracted in } \\
1 \% \text { hydrochloric acid in } 95 \% \\
\text { ethanol. }\end{array}$ & $\begin{array}{l}\text { I.schlecteri./I. } \\
\text { hawkeri }\end{array}$ & $\begin{array}{l}\text { Clevenger } \\
(1958)\end{array}$ \\
\hline Malvidin 3-O-glucoside & $\mathrm{C}_{23} \mathrm{H}_{25} \mathrm{O}_{12}+$ & $\begin{array}{l}(2 S, 3 R, 4 S, 5 S, 6 R) \text {-2- [5,7-di-hidroxi-2- (4-hidroxi- } \\
\text { 3,5-dimetoxifenil) cromenilio-3-il] oxi-6- } \\
\text { (hidroximetil) oxano-3,4,5-triol }\end{array}$ & $\begin{array}{l}\text { Extraction was performed by } \\
\text { immersing fresh petals in } 2 \% \\
\text { methanolic hydrochloric acid } \\
\text { immediately after harvest. }\end{array}$ & I. textori & $\begin{array}{l}\text { Ueno et al. } \\
\text { (1969) }\end{array}$ \\
\hline $\begin{array}{l}\text { Malvidin 3-O-(6"-malonyl) } \\
\text { glucoside }\end{array}$ & & & $\begin{array}{l}\text { The dried flowers were immersed } \\
\text { in } 5 \% \text { ethanolic acid at room } \\
\text { temperature and extracted } \\
\text { overnight. }\end{array}$ & I. textori & $\begin{array}{l}\text { Tatsuzawa et al. } \\
\text { (2009) }\end{array}$ \\
\hline Malvidin 3,5-di-O-glucoside & $\mathrm{C}_{29} \mathrm{H}_{35} \mathrm{O}_{17}+$ & $\begin{array}{l}(2 S, 3 R, 4 S, 5 S, 6 R)-2-[7-h y d r o x y-2-(4-h y d r o x y-3,5- \\
\text { dimethoxyphenyl)-3-[(2S,3R,4S,5S,6R)-3,4,5- } \\
\text { trihydroxy-6-(hydroxymethyl)oxan-2-yl] } \\
\text { oxychromenylium-5-yl]oxy-6-(hydroxymethyl) } \\
\text { oxane-3,4,5-triol }\end{array}$ & $\begin{array}{l}\text { Extraction was performed by } \\
\text { immersing fresh petals in } 2 \% \\
\text { methanolic hydrochloric acid } \\
\text { immediately after harvest. }\end{array}$ & I. textori & $\begin{array}{l}\text { Ueno et al. } \\
\text { (1969) }\end{array}$ \\
\hline $\begin{array}{l}\text { Malvidin 3-O-[6"-O-(3- } \\
\text { hydroxy-3- } \\
\text { methylglutaryl)- } \\
\beta \text {-glucopyranoside] }\end{array}$ & & & $\begin{array}{l}\text { The dried flowers were immersed } \\
\text { in } 5 \% \text { ethanolic acid at room } \\
\text { temperature and extracted } \\
\text { overnight. }\end{array}$ & I. textori & $\begin{array}{l}\text { Tatsuzawa et al. } \\
\text { (2009) }\end{array}$ \\
\hline Pelargonidin & $\mathrm{C}_{15} \mathrm{H}_{11} \mathrm{O}_{5}+$ & 2-(4-hydroxyphenyl)chromenylium-3,5,7-triol & $\begin{array}{l}\text { The extraction was performed with } \\
\text { material macerated in } 70 \% \text { ethanol } \\
\text { containing } 0.4 \% \text { hydrochloric acid } \\
(\mathrm{v} / \mathrm{v}) \text {. }\end{array}$ & I. balsamina & $\begin{array}{l}\text { Alston and } \\
\text { Hagen (1958) }\end{array}$ \\
\hline Pelargonidin 3-O-glucoside & $\mathrm{C}_{21} \mathrm{H}_{21} \mathrm{O}_{10}+$ & $\begin{array}{l}(2 S, 3 R, 4 S, 5 S, 6 R)-2-[5,7-d i h y d r o x y-2-(4- \\
\text { hydroxyphenyl)chromenylium-3-yl]oxy-6- } \\
\text { (hydroxymethyl)oxane-3,4,5-triol }\end{array}$ & $\begin{array}{l}\text { The extraction was performed with } \\
\text { material macerated in } 70 \% \text { ethanol } \\
\text { containing } 0.4 \% \text { hydrochloric acid } \\
(\mathrm{v} / \mathrm{v}) \text {. }\end{array}$ & I. balsamina & $\begin{array}{l}\text { Klein and Hagen } \\
\text { (1961) }\end{array}$ \\
\hline $\begin{array}{l}\text { Pelargonidin } 3,5-O- \\
\quad \text { diglucoside }\end{array}$ & $\mathrm{C}_{27} \mathrm{H}_{31} \mathrm{ClO}_{15}$ & $\begin{array}{l}\text { (2S,3R,4S,5S,6R)-2-[7-hydroxy-2-(4- } \\
\text { hydroxyphenyl)-3-[(2S,3R,4S,5S,6R)-3,4,5- } \\
\text { trihydroxy-6-(hydroxymethyl)oxan-2-yl] } \\
\text { oxychromenylium-5-yl]oxy-6-(hydroxymethyl) } \\
\text { oxane-3,4,5-triol; chloride }\end{array}$ & $\begin{array}{l}\text { The extraction was performed with } \\
\text { material macerated in } 70 \% \text { ethanol } \\
\text { containing } 0.4 \% \text { hydrochloric acid } \\
(\mathrm{v} / \mathrm{v}) \text {. }\end{array}$ & I. balsamina & Hagen (1966) \\
\hline $\begin{array}{l}\text { Pelargonidin 3-O-glucoside- } \\
\text { 5-O-acetylglucoside }\end{array}$ & & & $\begin{array}{l}\text { The extraction was performed with } \\
\text { material macerated in } 70 \% \text { ethanol } \\
\text { containing } 0.4 \% \text { hydrochloric acid } \\
(v / v) \text {. }\end{array}$ & I. balsamina & Hagen (1966) \\
\hline Peonidin & $\mathrm{C}_{16} \mathrm{H}_{13} \mathrm{O}_{6}+$ & $\begin{array}{l}\text { 2-(4-hydroxy-3-methoxyphenyl)chromenylium- } \\
\text { 3,5,7-triol }\end{array}$ & $\begin{array}{l}\text { The pigments were extracted at } \\
\text { room temperature with } 1 \% \\
\text { hydrochloric acid in } 95 \% \text { ethyl } \\
\text { alcohol }(\mathrm{v} / \mathrm{v}) \text {. }\end{array}$ & I. balsamina & $\begin{array}{l}\text { Klein and Hagen } \\
\text { (1961) }\end{array}$ \\
\hline Peonidin 3-O-glucoside & $\mathrm{C}_{22} \mathrm{H}_{23} \mathrm{O}_{11}+$ & $\begin{array}{l}\text { 2-[5,7-dihydroxy-2-(4-hydroxy-3-methoxyphenyl) } \\
\text { chromenylium-3-yl] oxy-6-(hydroxymethyl)oxane- } \\
\text { 3,4,5-triol }\end{array}$ & $\begin{array}{l}\text { Extraction with } 50 \% \text { ethanol and } \\
\text { then introduced in a sonication } \\
\text { bath, at a frequency of } 35 \mathrm{kHz} \text {. }\end{array}$ & I. noli-tangere & $\begin{array}{l}\text { Paun et al. } \\
\text { (2018) }\end{array}$ \\
\hline
\end{tabular}


Table 3 (continued)

\begin{tabular}{|c|c|c|c|c|c|}
\hline Compound Name & $\begin{array}{l}\text { Molecular } \\
\text { Formula }\end{array}$ & IUPAC Name & Extraction Methodology & Species & References \\
\hline \multirow[t]{2}{*}{ Leucocyanidin } & $\mathrm{C}_{15} \mathrm{H}_{14} \mathrm{O}_{7}$ & $\begin{array}{l}\text { 2-(3,4-dihydroxyphenyl)-3,4-dihydro-2H- } \\
\text { chromene-3,4,5,7-tetrol }\end{array}$ & $\begin{array}{l}\text { The pigments were extracted from } \\
\text { petals (or sepals) with } 1 \% \text { ethanolic } \\
\text { hydrochloric acid. }\end{array}$ & I. capensis & $\begin{array}{l}\text { Clevenger } \\
(1958)\end{array}$ \\
\hline & & & $\begin{array}{l}\text { Extraction made with hydrochloric } \\
\text { acid, in addition to leaf tissue in test } \\
\text { tubes, containing } 5 \mathrm{~g} \text { of sample and } \\
5 \mathrm{ml} \text { of hydrochloric acid. }\end{array}$ & $\begin{array}{l}\text { I.glandulifera./ } \\
\text { I. parviflora }\end{array}$ & $\begin{array}{l}\text { Bathe-Smith, } \\
1962\end{array}$ \\
\hline Leucodelphinidin & $\mathrm{C}_{15} \mathrm{H}_{14} \mathrm{O}_{8}$ & $\begin{array}{l}(2 S, 3 S, 4 R)-2-(3,4,5 \text {-trihydroxyphenyl)-3,4-dihydro- } \\
2 H \text {-chromene-3,4,5,7-tetrol }\end{array}$ & $\begin{array}{l}\text { Extraction made with hydrochloric } \\
\text { acid, in addition to leaf tissue in test } \\
\text { tubes, containing } 5 \mathrm{~g} \text { of sample and } \\
5 \mathrm{ml} \text { of hydrochloric acid. }\end{array}$ & I. parviflora & $\begin{array}{l}\text { Bathe-Smith, } \\
1962\end{array}$ \\
\hline
\end{tabular}

studied species (Impatiens balfourii Hook.f., I. balsamina, Impatiens capensis Meerb., Impatiens flaccida Arn., Impatiens linearifolia Warb., Impatiens platypetala Lindl, Impatiens schlechteri Warb, I. walleriana, Impatiens uguenensis Warb and several hybrid cultivars) (Thakur \& Nozzolillo, 1978).

Numerous studies conducted with the genus Impatiens have reported the existence of anthocyanin compounds, such as cyanidin fragments in the species I. canpensis, I. noli-tangere (Szewczyk, 2018). While the leucocyanidin traces were pointed out by Clevenger (1958) and Bathe-Smith (1962), respectively in the species I. glandulifera, I. parflivora and I. canpensis and leucodelfinidin were present in I. parflivora. More specifically, Ueno, Takemura, and Hayashi (1969) and Tatsuzawa et al. (2009), identified the compounds malvidin-3-O-glucoside, malvadin-3-O-(6 "-malonyl) glucoside and malvidin-3, 5-di-O-glucoside in samples of Impatiens textori Miq., While peonidin-3-O-glucoside was identified by Paun et al. (2018) in extracts of I. noli-tangere. These and more other compounds were identified, as shown in Table 3.

\subsection{Health benefits associated with consumption of impatiens genus}

The genus Impatiens have a great relevance in the Asian traditional medicine, mainly in countries such as China, India, Korea and Taiwan (Delgado-Rodriguez, Hidalgo, Loría-Guitiérrez \& Weng-Huang, 2017). Different parts of this plant are used in various treatments, such as occasional wounds from thorns, perforations made by glass, abscesses, scrofulose, carbuncles, diarrhea, rheumatism, fractures, superficial infections and even inflammation of the nails (Kang et al., 2013). In the Eastern tradition, infusions of this plant are applied to the skin, in order to relieve bacterial and fungal infections (Kang et al., 2013). In some areas of China, however, beliefs are widespread regarding the relationship between the use of this genus in the treatment of cancers, although there is no confirmation about the efficiency of this practice (Ding, Jiang, Chen, Ly, Zhu, 2008).

Delgado-Rodriguez, Hidalgo, Loría-Gutiérrez, and Weng-Huang (2017) claims that several plants of this genus have the potential to reduce infectious and inflammatory diseases. Otherwise, several studies have already claimed the presence of relevant pharmacological effects present (Ju, Kong, \& Li, 2007). Among these effects, antimicrobial (Delgado-Rodriguez et al., 2017; Manikandan, Rajendran, Abirami, \& Kongarasi, 2016; Su et al., 2012), antioxidant (Mushtaq et al., 2013; Paun et al., 2018; Szewczyk, Kalemba, Komsta, \& Nowak, 2016b) and anti-inflammatory (Delgado-Rodriguez et al., 2017; Sun et al., 2015) activities stand out. Thus other activities such as anti-rheumatic (Kang et al., 2013), anti-pruritic (Kang et al., 2013), antifungal (Nisar et al., 2010), anti-allergic (Kang et al., 2013), anti-tumor (Cimmino et al., 2016), anti-dermatitic (Motz et al., 2015), anti-platelet (Ueda, Oku, Iinuma, \& Ishiguro, 2003), anti-anaphylactic (Fukumoto, Yamaki, Isoi, \& Ishiguro, 1996; Ishiguro et al., 1992; Ueda, Oku, Iinuma, \& Ishiguro, 2005), anti-neurodegenerative (Kim, Bae, Subedi, Suh, Choi \& Lee, 2017) and antinociceptive (Imam et al., 2012) have also been reported. This and other bioactivities can be seen according to Table 4 .
Gunawardana and e Jayasuriya (2019), pointed out several attributes referring to the health benefits provided by the use of I. balsamina as a medicinal plant in Sri Lanka. Its freshness, demulcent, tonic, anti-anaphylactic and anti-hypotensive properties stand out, while its methanolic extract manages to directly combat some fungi and pathogenic bacteria, as well as its methanolic extracts which revealed anti-tumor and anti-nociceptive activities.

Szewczyk, Zidorn, Biernasiuk, Komsta, and Granica (2016b), studied the antibacterial and antioxidant activities of the extracts (methanol/acetone/water $(3 / 1 / 1, \mathrm{v} / \mathrm{v} / \mathrm{v} ; 3 \times 50 \mathrm{ml})$ of aerial parts of six species of the genus Impatiens, among the results, as species I. balsamina and I. glandulifera demonstrated a greater spectrum of antibacterial activity, but all species greater performance against Gram-positive bacteria.

Ethanol extracts from leaves of I. balsamina were effective in eliminating radicals and combating microorganisms when evaluated by the Free Radical Scavenging Activity on DPPH method and by antimicrobial assays, the same authors mention that the delay in the harvest time provided an increase in the total phenolic content and in the ability to inhibit the formation of free radicals (Kang et al., 2013). While, John and Koperuncholan (2012), observed the antibacterial activity of I. balsamina hexane, petroleum ether, acetone, methanol and water extracts, using the disk diffusion method. The tests were performed against bacterial pathogens namely Shigella boydii, Salmonella paratyphii, Proteus vulgaris, Staphylococcus aureus, Candida albicans and Cryptococcus neoformans. Among the conclusions, I. balsamina presented unique characteristics against these microorganisms, having a high potential in the development of new drugs.

Zheng, Hu, et al. (2019) tested the therapeutic effects of I. balsamina against androgenic alopecia in mice, where hair growth was observed in dorsal lesions of rodents, due to a reduction in androgen content. Similarly, Imam et al. (2012) obtained good results in relation to the antinociceptive activity of the methanolic extract of flowers of I. balsamina applied in rodents, who had less perception of pain in different conditions, in order to prove the efficiency of the extract used by medicine traditional treatment for burns, low back pain, neuralgia and burns.

Li et al. (2017), states that all organs of Impatiens can be applied not only for medicinal applications, but also as an alternative functional food. In addition, it reinforces that the bioactivity of saponins present in this plant can confer positive results regarding anti-hepatic fibrosis, in order to arouse interest in its use as a functional food.

\subsection{Applications in the food industry}

Nowadays, there is a demand for healthier and more natural foods, as many consumers have raised concerns about possible health hazards, especially with the adoption of synthetic additives in the composition of foods (Carocho, Morales, \& Ferreira, 2015; Lachno, Dutra, Severo, dos Santos Oliveira, \& de Oliveira, 2019). Many food industries are looking more frequently for healthy alternatives of ingredients and additives 
Table 4

Bioactivities discovered in the genus Impatiens.

\begin{tabular}{|c|c|c|c|c|}
\hline Scientific Name & Part of the plant & Extract & Bioactivites & References \\
\hline $\begin{array}{l}\text { Impatiens balfourii } \\
\text { Hook.f. (1903) }\end{array}$ & Aerial parts & $\begin{array}{l}\text { The samples were sonicated with a mixture of methanol/acetone/water for } \\
30 \mathrm{~min} \text { at a controlled temperature. }\end{array}$ & $\begin{array}{l}\text { Antimicrobial and } \\
\text { antioxidant }\end{array}$ & $\begin{array}{l}\text { Szewczyk, Zidorn, Biernasiuk, } \\
\text { Komsta, and Granica (2016) }\end{array}$ \\
\hline \multirow{16}{*}{$\begin{array}{l}\text { Impatiens } \\
\text { balsamina } \mathrm{L} . \\
\text { (1753). }\end{array}$} & Aerial parts & $\begin{array}{l}\text { The samples were sonicated with a mixture of methanol/acetone/water for } \\
30 \mathrm{~min} \text { at a controlled temperature. }\end{array}$ & $\begin{array}{l}\text { Antimicrobial and } \\
\text { antioxidant }\end{array}$ & Szewczyk, Zidorn, et al. (2016) \\
\hline & Roots and & Firstly, an extraction with hot water by sonication was carried out, and & Antioxidant & Szewczyk, Heise, and \\
\hline & $\begin{array}{l}\text { aerial parts } \\
\text { Whole plant }\end{array}$ & $\begin{array}{l}\text { then a second extraction with } 2 \% \text { isoamyl alcohol in chloroform. } \\
\text { The material was macerated with } 80 \%(\mathrm{v} / \mathrm{v}) \text { ethanol, then it was protected }\end{array}$ & & $\begin{array}{l}\text { Piwowarski (2018) } \\
\text { Delgado-Rodriguez et al. (2017) }\end{array}$ \\
\hline & material & from light and temperature. & & \\
\hline & Stems & $\begin{array}{l}\text { The plant material was extracted by the ultrasound method, in which } \\
\text { several solvents were used (petroleum ether, diethyl ether, chloroform, } \\
\text { methanol and water). }\end{array}$ & & Su et al. (2012) \\
\hline & $\begin{array}{l}\text { Whole plant } \\
\text { material }\end{array}$ & $\begin{array}{l}\text { The material was macerated with } 80 \%(\mathrm{v} / \mathrm{v}) \text { ethanol, then it was protected } \\
\text { from light and temperature. }\end{array}$ & Antimicrobial & Delgado-Rodriguez et al. (2017) \\
\hline & Seeds & $\begin{array}{l}\text { The seeds were suspended in haxane and remained in infusion for two days } \\
\text { at room temperature with agitation. }\end{array}$ & & Manikandan et al. (2016) \\
\hline & Stems & $\begin{array}{l}\text { The plant material was extracted by the ultrasound method, in which } \\
\text { several solvents were used (petroleum ether, diethyl ether, chloroform, } \\
\text { methanol and water). }\end{array}$ & & Su et al. (2012) \\
\hline & Aerial parts & Extract was obtained from $95 \%$ ethanol $(\mathrm{v} / \mathrm{v})$ & & Yang et al. (2001) \\
\hline & Seeds & $\begin{array}{l}\text { The protein was extracted from the seeds and, then, precipitation and } \\
\text { dialysis with ammonium sulfate were performed. }\end{array}$ & & Patel et al. (1998) \\
\hline & Flowers & $\begin{array}{l}\text { The extract was obtained from the flowers with } 75 \% \text { ethanol, then } \\
\text { suspended in water and then divided with petroleum ether, } \\
\text { dichloromethane, ethyl acetate and n-butanol. }\end{array}$ & Anti-hepatic & Li et al. (2017) \\
\hline & Leaves & $\begin{array}{l}\text { The leaves powder was dissolved with } 96 \% \text { solvent ethanol, stirred, left for } \\
\text { five days, then filtered. }\end{array}$ & Antibacterial & $\begin{array}{l}\text { Mahyun, Kusuma, and Anshory } \\
\text { (2018) }\end{array}$ \\
\hline & $\begin{array}{l}\text { Pods, Roots, } \\
\text { Stems and } \\
\text { Leaves }\end{array}$ & $\begin{array}{l}\text { The sample was put in contact with acetone, followed by stirring and } \\
\text { remained at room temperature for } 1 \mathrm{~h} \text { and, afterwards, was centrifuged. }\end{array}$ & & Wang et al. (2011) \\
\hline & Flowers & $\begin{array}{l}\text { The extract was obtained from flowers with } 75 \% \text { ethanol, then } \\
\text { concentrated, suspended in water and partitioned with petroleum ether, } \\
\text { dichloromethane, ethyl acetate and n-butanol. }\end{array}$ & Anti-diabetic & Li, Zhang, et al. (2015) \\
\hline & Flowers & $\begin{array}{l}\text { The extract was obtained from flowers with } 75 \% \text { ethanol, then } \\
\text { concentrated, suspended in water and partitioned with petroleum ether, } \\
\text { dichloromethane, ethyl acetate and n-butanol. }\end{array}$ & Anti-hepatic & Li, Zhang, et al. (2015) \\
\hline & Flowers & $\begin{array}{l}\text { The dried flowers were macerated in methanol with agitation for } 3 \text { days, } \\
\text { then the extract was filtered. }\end{array}$ & Antinoceptive & Imam et al. (2012) \\
\hline $\begin{array}{l}\text { Impatiens bicolor } \\
\text { Royle }\end{array}$ & Aerial parts & $\begin{array}{l}\text { The extract was obtained through the solvents n-hexane, dichloromethane, } \\
\text { ethyl acetate, n-butanol, aqueous and crude. }\end{array}$ & $\begin{array}{l}\text { Antibacterial and } \\
\text { antifungal }\end{array}$ & $\begin{array}{l}\text { Nisar et al. (2010) } \\
\text { Nisar et al. (2010) }\end{array}$ \\
\hline $\begin{array}{l}\text { Impatiens capensis } \\
\quad \text { Meerb }\end{array}$ & Leaves & $\begin{array}{l}\text { The leaves were extracted in } 50 \% \text { methanol for one week at room } \\
\text { temperature without shaking. The extract was then stirred for } 24 \mathrm{~h} \text { at room } \\
\text { temperature and filtered under vacuum. }\end{array}$ & Anti-dermatitic & Motz et al. (2015) \\
\hline \multirow{5}{*}{$\begin{array}{l}\text { Impatiens } \\
\quad \text { glandulifera } \\
\text { Royle }\end{array}$} & $\begin{array}{l}\text { Roots and } \\
\text { Aerial parts. }\end{array}$ & $\begin{array}{l}\text { Firstly, an extraction with hot water by sonication was carried out, and } \\
\text { then a second extraction with } 2 \% \text { isoamyl alcohol in chloroform. }\end{array}$ & Cytotoxic & $\begin{array}{l}\text { Szewczyk, Heise, and } \\
\text { Piwowarski (2018) }\end{array}$ \\
\hline & $\begin{array}{l}\text { Roots and } \\
\text { Aerial parts }\end{array}$ & $\begin{array}{l}\text { Firstly, an extraction with hot water by sonication was carried out, and } \\
\text { then a second extraction with } 2 \% \text { isoamyl alcohol in chloroform. }\end{array}$ & Antioxidant & $\begin{array}{l}\text { Szewczyk, Heise, and } \\
\text { Piwowarski (2018) }\end{array}$ \\
\hline & $\begin{array}{l}\text { Leaves, Flowers } \\
\text { and Roots }\end{array}$ & $\begin{array}{l}\text { The samples were extracted with sonication in an ethanol/water mixture } \\
\text { at a temperature controlled by } 30 \mathrm{~min} \text {. }\end{array}$ & $\begin{array}{l}\text { Antinocepitive and } \\
\text { antianxiety }\end{array}$ & $\begin{array}{l}\text { Szewczyk, Orzelska-Gorka, } \\
\text { Polakowska, and Biala (2018a) } \\
\text { Szewczyk, Orzelska-Gorka, et al. } \\
\text { (2018b) }\end{array}$ \\
\hline & Aerial parts & $\begin{array}{l}\text { The samples were sonicated with a methanol/acetone/water mixture at a } \\
\text { controlled temperature for } 30 \mathrm{~min} \text {. }\end{array}$ & $\begin{array}{l}\text { Antimicrobial and } \\
\text { antioxidant }\end{array}$ & Szewczyk, Zidorn, et al. (2016) \\
\hline & $\begin{array}{l}\text { Roots, Stems } \\
\text { and Leaves }\end{array}$ & $\begin{array}{l}\text { The plant material was extracted twice with n-hexane, ethyl acetate and } \\
\text { methanol under stirring conditions for } 4 \mathrm{~h} \text {. }\end{array}$ & Anti-tumor & Cimmino et al. (2016) \\
\hline \multirow[t]{7}{*}{$\begin{array}{l}\text { Impatiens noli- } \\
\quad \text { tangere } \mathrm{L} .\end{array}$} & Aerial parts & $\begin{array}{l}\text { The samples were sonicated with a methanol/acetone/water mixture at a } \\
\text { controlled temperature for } 30 \mathrm{~min} \text {. }\end{array}$ & $\begin{array}{l}\text { Antimicrobial and } \\
\text { antioxidant }\end{array}$ & Szewczyk, Zidorn, et al. (2016) \\
\hline & \multirow[t]{2}{*}{$\begin{array}{l}\text { Roots and } \\
\text { Aerial parts }\end{array}$} & \multirow{2}{*}{$\begin{array}{l}\text { Firstly, an extraction with hot water by sonication was carried out, and } \\
\text { then a second extraction with } 2 \% \text { isoamyl alcohol in chloroform. } \\
\text { Firstly, an extraction with hot water by sonication was carried out, and } \\
\text { then a second extraction with } 2 \% \text { isoamyl alcohol in chloroform. }\end{array}$} & Cytotoxic & $\begin{array}{l}\text { Szewczyk, Heise, and } \\
\text { Piwowarski (2018) }\end{array}$ \\
\hline & & & \multirow[t]{2}{*}{ Antioxidant } & Szewczyk et al., 2018c \\
\hline & $\begin{array}{l}\text { Dry leaves and } \\
\text { Stems }\end{array}$ & $\begin{array}{l}\text { The extraction was carried out with } 50 \% \text { ethanol and then introduced in a } \\
\text { sonication bath for } 90 \mathrm{~min} \text {. }\end{array}$ & & Paun et al. (2018) \\
\hline & Leaves, Flowers & The samples were extracted with sonication in an ethanol/water mixture & Antinocepitive and & Szewczyk (2018) \\
\hline & and Roots & at a temperature controlled by $30 \mathrm{~min}$. & antianxiety & Szewczyk (2018) \\
\hline & $\begin{array}{l}\text { Dry leaves and } \\
\text { Stems }\end{array}$ & $\begin{array}{l}\text { The extraction was carried out with } 50 \% \text { ethanol and then introduced in a } \\
\text { sonication bath for } 90 \mathrm{~min} \text {. }\end{array}$ & Anti-inflammatory & Paun et al. (2018) \\
\hline \multirow[t]{4}{*}{$\begin{array}{l}\text { Impatiens parviflora } \\
\text { DC. }\end{array}$} & Aerial parts & $\begin{array}{l}\text { The samples were sonicated with a methanol/acetone/water mixture at a } \\
\text { controlled temperature for } 30 \mathrm{~min} \text {. }\end{array}$ & $\begin{array}{l}\text { Antimicrobial and } \\
\text { antioxidant }\end{array}$ & Szewczyk, Zidorn, et al. (2016) \\
\hline & \multirow{3}{*}{$\begin{array}{l}\text { Roots and } \\
\text { Aerial parts } \\
\text { Leaves, Flowers } \\
\text { and Roots }\end{array}$} & \multirow{3}{*}{$\begin{array}{l}\text { Firstly, an extraction with hot water by sonication was carried out, and } \\
\text { then a second extraction with } 2 \% \text { isoamyl alcohol in chloroform. } \\
\text { The samples were extracted with sonication in an ethanol/water mixture } \\
\text { at a temperature controlled by } 30 \mathrm{~min} \text {. }\end{array}$} & Antioxidant & $\begin{array}{l}\text { Szewczyk, Heise, and } \\
\text { Piwowarski (2018) }\end{array}$ \\
\hline & & & Antinocepitive & $\begin{array}{l}\text { Szewczyk, Orzelska-Gorka, et al. } \\
\text { (2018b) }\end{array}$ \\
\hline & & & Antianxiety & $\begin{array}{l}\text { Szewczyk, Orzelska-Gorka, et al. } \\
\text { (2018b) }\end{array}$ \\
\hline
\end{tabular}


Table 4 (continued)

\begin{tabular}{|c|c|c|c|c|}
\hline Scientific Name & Part of the plant & Extract & Bioactivites & References \\
\hline $\begin{array}{l}\text { Impatiens textori } \\
\text { Miq. }\end{array}$ & Flowers & The extract was obtained from a solution containing $35 \%$ ethanol (v/v). & $\begin{array}{l}\text { Antipruritic, } \\
\text { Antianaphylactic and } \\
\text { antiplatelet }\end{array}$ & $\begin{array}{l}\text { Ueda et al. (2005) } \\
\text { Ueda et al. (2005) } \\
\text { Ueda et al. (2003) }\end{array}$ \\
\hline $\begin{array}{l}\text { Impatiens } \\
\text { walleriana Hook. }\end{array}$ & Aerial parts & $\begin{array}{l}\text { The samples were sonicated with a methanol/acetone/water mixture at a } \\
\text { controlled temperature for } 30 \mathrm{~min} \text {. }\end{array}$ & $\begin{array}{l}\text { Antimicrobial and } \\
\text { antioxidant }\end{array}$ & Szewczyk, Zidorn, et al. (2016) \\
\hline f. & $\begin{array}{l}\text { Whole plant } \\
\text { material }\end{array}$ & $\begin{array}{l}\text { The material was macerated with } 80 \%(\mathrm{v} / \mathrm{v}) \text { ethanol, then it was protected } \\
\text { from light and temperature. }\end{array}$ & $\begin{array}{l}\text { Antioxidant and } \\
\text { antimicrobial }\end{array}$ & $\begin{array}{l}\text { Delgado-Rodriguez et al. (2017) } \\
\text { Delgado-Rodriguez et al. (2017) }\end{array}$ \\
\hline
\end{tabular}

that offer less impact related to the individual's health. (Pinela et al., 2019). While, research is carried out, in order to identify new food matrices, for the preparation of additives, which provide health benefits through their bioactivities and do not harm the environment, such as, for example, natural green colorants (Vieira, Pérez-Gálvez \& Roca, 2019).

Edible flowers are being investigated in order to be applied as possible matrices for the preparation of food additives (Pinela et al., 2019). Martins et al. (2013) for example, incorporated phenolic extracts from the flowers of Rubus ulmifolius Schoot, in yogurt formulations, in order to enhance antioxidant activity. Carocho et al. (2016), used the chestnut flower as a functional and preserving agent in a famous Serra da Estrela cheese. In its turn, Pontes (2019) incorporated ethanolic extracts from leaves and flowers of Malvaviscus arboreus Cav. For the preparation of goat hamburgers, to extend the shelf. Almeida and Schweig (2018), developed and evaluated the sensory characteristics of gluten-free cookies with the addition of Hibiscus rosa-sinensis L. while Cielo (2018) developed and sensorially tested yogurts added with rose petal jam.

In general, many plants are used as matrices for the extraction of the most diverse ingredients and additives for the food industry. Chen et al. (2019) reported the presence of a new food dye (Lemon yellow \# 15) highly stable and soluble in water, from the ethanolic extract of Citrus limon. Patras (2019), tested the interaction of nineteen food additives/ingredients on the stability and colour parameters of the hydroethanolic extract of red cabbage residues, in order to measure its potential as a colorant. Domínguez et al. (2020), stated that by-products from tomatoes can be used as natural additives for meat products, in order to promote their nutritional quality, increase product stability, reduce lipid oxidation and among other benefits. Pinela et al. (2019) in turn, optimized the anthocyanins extraction process present in the $\mathrm{Hi}$ biscus sabdariffa calyces, with an alternative to obtain a new food coloring.

However, the industrial application of flowers of the genus Impatiens is still scarce and little explored. Szewczyk, Zidorn, Biernasiuk, Komsta, and Granica (2016b) argues that the extracts of I. balfourii, I. glandulifera and I. parviflora are considerable sources of natural antioxidants, in which they can be designated for the development of food additives and nutraceuticals. In turn, Su, Cao, Fan, Yang \& Zhang (2007) they extracted a natural edible pigment from the garden balsam (I. balsamina), in which it was found that both the stems and their pigmented parts have relevant values for use. Sultan (2003), on the other hand, extracted a yellow colorant from Impatiens spp, stating that these plants are low-cost sources and easy to extract colorants, and that they can provide added value and economic benefits. According to CABI (2020), the dry stems of the species I. parviflora can be used as a food source in situations of scarcity, while the species I. balsamina is applied as a colorant for dyeing hair, nails, hands and feet of women in Asia.

In this way, it can be emphasized that this type of plants presents themselves as a possible matrix for the development of food additives, mainly the petals, due to the attractiveness of its colors. However, further studies are necessary to understand the safety of these additives. Finally, it can be seen that many studies prove the existence of several bioactive compounds in many edible flowers, including Impatiens. Thus, edible flowers can be an opportunity for innovation in the food segment (Benvenuti et al., 2016). In addition, it can be said that studies on the use of edible flowers as food ingredients are constant in terms of research.

\section{Concluding remarks}

The present manuscript demonstrates edible flowers as a source of a multitude of bioactive compounds focusing on the genus Impatiens, which, despite the scarce studies available, it reveals to be an interesting matrix, showing different groups of compounds, such flavonoids, coumarins and phenolic acids, justifying the numerous bioactivities described for this genus. In addition, its attractive colors are given by anthocyanin compounds that may be of high interest to the food industry, which seeks to explore alternative colorants.

Currently, consumers demand healthier, natural and healthpromoting products and, consequently, there has been a great pressure in different industries to apply natural matrices in the development of innovative products. In this sense, this review brings together studies regarding the nutritional and chemical characterization of flowers of the genus Impatiens, as well as a detailed study of several bioactivities highlighted for each species of this genus. This study also shows itself as a useful tool for various industries, namely, food, pharmaceutical and cosmetics in the future exploration of the genus Impatiens.

\section{Future trends and/or challenges}

The acceptance of edible flowers in the human diet, as well as the application of its components in the food industry, is still a challenge to be overcome. The exploration of bioactive compounds as natural ingredients and health promoters and their application in innovative products, emerges as a desire of the food industry, but also, of the pharmaceutical and cosmetic industry. However, the stability and biostability of this type of compound appears as the biggest challenge and still needs several studies that can guarantee the effectiveness of these compounds for human consumption. The exploitation of matrices used since antiquity with recognized properties by the traditional medicine has aroused a high interest and its industrial exploitation on a large scale is expected, which raises some environmental issues in such a way that the management of its exploitation also becomes a future challenge.

\section{Acknowledgements}

The authors are grateful to the Foundation for Science and Technology (FCT, Portugal) for financial support by national funds FCT/ MCTES to CIMO (UIDB/00690/2020). L. Barros would like to thank the national funding by FCT, P.I., through the institutional scientific employment program-contract. To the project AllNat for the contract of C. Caleja (Project AllNat POCI-01-0145-FEDER-030463). The authors are also grateful to the project TRANSCoLAB 0612_TRANS_CO_LAB_2_P. This work is funded by the European Regional Development Fund (ERDF) through the Regional Operational Program North 2020, within the scope of Project Mobilizador Norte-01-0247-FEDER-024479: ValorNatural ${ }^{\circledR}$, Norte-01-0145-FEDER-000042: Project GreenHealth. This work was also financed by ERDF, through the Incentive System to Research and Technological Development, within the Portugal2020 Competitiveness and Internationalization Operational Program, for the project POCI-01-0247-FEDER-046112: BIOMA. 


\section{References}

Abbet, C., Mayor, R., Roguet, D., Spichiger, R., Hamburger, M., \& e Potterat, O. (2014) Ethnobotanical survey on wild alpine food plants in Lower and Central Valais (Switzerland). Journal of Ethnopharmacology, 151(1), 624-634. https://doi.org/ 10.1016/j.jep.2013.11.022

Albuquerque, B. R., Prieto, M. A., Barreiro, M. F., Rodrigues, A., Curran, T. P., Barros, L., et al. (2017). Catechin-based extract optimization obtained from Arbutus unedo L. fruits using maceration/microwave/ultrasound extraction techniques. Industrial Crops and Products, 95, 404-415. https://doi.org/10.1016/j.indcrop.2016.10.050

Almeida, K. D., \& Schweig, M. (2018). Elabora $\tilde{A} \S \tilde{A} £ o$ de biscoitos sem gl $\tilde{A}^{\circ}$ ten com farinha de hibisco e ricos em fibras (Bachelor's thesis, Universidade Tecnol $\tilde{A}^{3}$ gica Federal do Paran $\tilde{A}_{i}$ ). http://repositorio.roca.utfpr.edu.br/jspui/handle/1/15592.

Alston, R. E., \& Hagen, C. W., Jr. (1958). Chemical aspects of the inheritance of flower color in Impatiens balsamina L. Genetics, 43(1), 35.

Amchova, P., Kotolova, H., \& Ruda-Kucerova, J. (2015). Health safety issues of synthetic food colorants. Regulatory Toxicology and Pharmacology, 73(3), 914-922. https://doi. org/10.1016/j.yrtph.2015.09.026

Anastácio, L. B., Oliveira, D. A., Delmaschio, C. R., Antunes, L. M. G., \& Chequer, F. M. D. (2016). Corantes alimentícios amaranto, eritrosina B e tartazina, e seus possíveis efeitos maléficos à saúde humana. Journal of Applied Pharmaceutical Sciences JAPHAC, 2(3), 16-30.

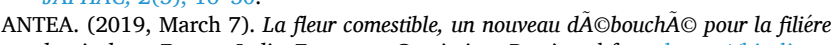
horticole en France, Italie. European Comission. Retrieved from https://bityli. $\mathrm{com} / \mathrm{jCFrc}$.

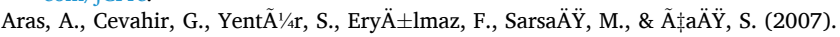
Investigation of anthocyanin localization in various parts of Impatiens balsamina $\mathrm{L}$ Biotechnology \& Biotechnological Equipment, 21(1), 69-73. https://doi.org/10.1080/ 13102818.2007.10817417

Bagby, M. O., Smith, C. R., \& Wolff, I. A. (1966). Stereochemistry of $\alpha$-parinaric acid from Impatiens edgeworthii seed oil. Lipids, 1(4), 263-267. https://doi.org/10.1007/ BF02531613

Barto, K., Friese, C., \& Cipollini, D. (2010). Arbuscular mycorrhizal fungi protect a native plant from allelopathic effects of an invader. Journal of Chemical Ecology, 36(4), 351-360. https://doi.org/10.1007/s10886-010-9768-4

Bathe-Smith, E. C. (1962). The phenolic constituents of plants and their taxonomic significance. I. Dicotyledons. Botanical Journal of the Linnean Society, 58(371), 95-173. https://doi.org/10.1111/j.1095-8339.1962.tb00890.x

Batten, R. (2015). Orange touch-me-not (Impatiens aurella) balsaminaceae (Touch-me-not family). Ministry of forests, lands and natural resource operations | thompson okanagan region, resource management, ecosystems section. https://www2.gov.bc.ca/assets/go v/environment/natural-resource-stewardship/best-management-practices/okanaga n/impatiens_aurella.pdf.

Benvenuti, S., Bortolotti, E., \& Maggini, R. (2016). Antioxidant power, anthocyanin content and organoleptic performance of edible flowers. Scientia Horticulturae, 199, 170-177. https://doi.org/10.1016/j.scienta.2015.12.052

Bleve, M., Ciurlia, L., Erroi, E., Lionetto, G., Longo, L., Rescio, L., et al. (2008). An innovative method for the purification of anthocyanins from grape skin extracts by using liquid and sub-critical carbon dioxide. Separation and Purification Technology, 64(2), 192-197. https://doi.org/10.1016/j.seppur.2008.10.012

Bohm, B. A., \& Towers, G. H. N. (1962). A study of phenolic compounds in Impatiens. Canadian Journal of Botany, 40(5), 677-683. https://doi.org/10.1139/b62-065

Britannica Academic. (2017). Enciclopédia britânica. Retrieved from https://bit ly/36dsY5Y.

CABI. (2020). Invasive species compendium. Wallingford, UK: CAB International. Retrieved from www.cabi.org/isc.

CABI. (2020a). Julissa Rojas-Sandoval. [original text by AN Author] Impatiens balsamina (garden balsam). In Invasive species compendium. Wallingford, UK: CAB International. Retrieved from www.cabi.org/isc.

CABI. (2020b). Julissa Rojas-Sandoval. [original text by AN Author] Impatiens walleriana (busy lizzy). In Invasive species compendium. Wallingford, UK: CAB International. Retrieved from www.cabi.org/isc.

CABI. (2020c). Kate pollard \& rob tanner. [original text by AN author] Impatiens glandulifera (himalayan balsam). In Invasive species compendium. Wallingford, UK: CAB International. Retrieved from www.cabi.org/isc.

CABI. (2020d). Rob tanner \& bakeham lane. [original text by AN author] Impatiens parviflora (small balsam). In Invasive species compendium. Wallingford, UK: CAB International. Retrieved from www.cabi.org/isc.

Carocho, M., Morales, P., \& Ferreira, I. C. (2015). Natural food additives: Quo vadis? Trends in Food Science \& Technology, 45(2), 284-295. https://doi.org/10.1016/j. tifs.2015.06.007

Carocho, M., Barreira, J. C. M., Bento, A., Fernández-Ruiz, V., Morales, P., \& Ferreira, I. C. F. R. (2016). Chestnut and lemon balm based ingredients as natural preserving agents of the nutritional profile in matured "Serra da Estrela" cheese. Food Chemistry, 204, 185-193.

Carvalho, F. P. (2018). Avaliação da qualidade de flores comestíveis frescas e liofilizadas e estudo sobre consumo de flores comestiveis em Portugal.

Chen, X., Ding, Y., Forrest, B., Oh, J., Boussert, S. M., \& Hamann, M. T. (2019). Lemon yellow\# 15 a new highly stable, water soluble food colorant from the peel of Citrus limon. Food Chemistry, 270, 251-256. https://doi.org/10.1016/j. foodchem.2018.07.055

Chen, N. H., \& Wei, S. (2017). Factors influencing consumersâ $€^{\mathrm{TM}}$ attitudes towards the consumption of edible flowers. Food Quality and Preference, 56, 93-100. https://doi org/10.1016/j.foodqual.2016.10.001
Chua, L. S. (2016). Untargeted MS-based small metabolite identification from the plant leaves and stems of Impatiens balsamina. Plant Physiology and Biochemistry, 106, 16-22. https://doi.org/10.1016/j.plaphy.2016.04.040

Chugh, B., \& Kamal-Eldin, A. (2020). Bioactive compounds produced by probiotics in food products. Current Opinion in Food Science, 32, 76-82. https://doi.org/10.1016/j. cofs.2020.02.003

Cielo, D. P. (2018). Development of yoghurt with rose petal jam: Sensory perspectives and consumer study. Masterâ $€^{\mathrm{TM}} \mathrm{s}$ dissertation. Brazil: Universidade Federal de Santa Maria http://repositorio.ufsm.br/handle/1/19069.

Cimmino, A., Mathieu, V., Evidente, M., Ferderin, M., Banuls, L. M. Y., Masi, M., et al. (2016). Glanduliferins A and B, two new glucosylated steroids from Impatiens glandulifera, with in vitro growth inhibitory activity in human cancer cells. Fitoterapia, 109, 138-145. https://doi.org/10.1016/j.fitote.2015.12.016

Clevenger, S. (1958). The flavonols of Impatiens balsamina L. Archives of Biochemistry and Biophysics, 76(1), 131-138. https://doi.org/10.1016/0003-9861(58)90127-9

Clevenger, S. (1971). Anthocyanidins of Impatiens species. Evolution, 669-677. https:// doi.org/10.1111/j.1558-5646.1971.tb01924.x

Coultate, T., \& Blackburn, R. S. (2018). Food colorants: Their past, present and future. Coloration Technology, 134(3), 165-186. https://doi.org/10.1111/cote.12334

Cunningham, E. (2015). What nutritional contribution do edible flowers make? Journal of the Academy of Nutrition and Dietetics, 115(5), 856. https://doi.org/10.1016/j. jand.2015.03.002

Delgado-Rodriguez, F. V., Hidalgo, O., Loría-Gutiérrez, A., \& Weng-Huang, N. T. (2017). In vitro antioxidant and antimicrobial activities of ethanolic extracts from whole plants of three Impatiens species (balsaminaceae). Ancient Science of Life, 37(1), 16.

Ding, Z. S., Jiang, F. S., Chen, N. P., Lv, G. Y., \& e Zhu, C. G. (2008). Isolation and identification of an anti-tumor component from leaves of Impatiens balsamina. Molecules, 13(2), 220-229. https://doi.org/10.3390/molecules13020220

Domínguez, R., Gullón, P., Pateiro, M., Munekata, P. E., Zhang, W., \& Lorenzo, J. M. (2020). Tomato as potential source of natural additives for meat industry. A review. Antioxidants, 9(1), 73. https://doi.org/10.3390/antiox9010073

Espín, J. C., \& Tomas-Barberan, F. A. (2001). Phenolic compounds and related enzymes as determinants of fruits and vegetables. Journal of the Science of Food and Agriculture, 81(9), 853-876. https://doi.org/10.1002/jsfa.885

Essien, S. O., Young, B., \& Baroutian, S. (2020). Recent advances in subcritical water and supercritical carbon dioxide extraction of bioactive compounds from plant materials. Trends in Food Science \& Technology, 97, 156-169. https://doi.org/10.1016/j. tifs.2020.01.014

Fachun, W. A. N. G. (2008). Fatty acid compositions of Impatiens balsamina Linn seed oil [J] (Vol. 6). China Oils and Fats.

Fan, X., SchÃafer, H., Reichling, J., \& Wink, M. (2013). Bactericidal properties of the antimicrobial peptide Ibâ€AMP4 from Impatiens balsamina produced as a recombinant fusionâfprotein in Escherichia coli. Biotechnology Journal, 8(10), 1213-1220. https://doi.org/10.1002/biot.201300121

de Favari Tardivo, C., \& Meru, G. M. (2018). [HS1321] Production of edible Flowers in Florida. Environmental Data and Information Service, 2018(4).

Fernandes, L., Casal, S., Pereira, J. A., Saraiva, J. A., \& Ramalhosa, E. (2016). Edible

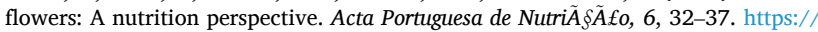
doi.org/10.21011/apn.2016.0606

Fernandes, L., Casal, S., Pereira, J. A., Saraiva, J. A., \& Ramalhosa, E. (2017). Edible flowers: A review of the nutritional, antioxidant, antimicrobial properties and effects on human health. Journal of Food Composition and Analysis, 60, 38-50. https://doi. org/10.1016/j.jfca.2017.03.017

Fernandes, L., Casal, S., Pereira, J. A., Saraiva, J. A., \& Ramalhosa, E. (2020). An overview on the market of edible flowers. Food Reviews International, 36(3), 258-275. https://doi.org/10.1080/87559129.2019.1639727

Fornefeld, E., Schierstaedt, J., Jechalke, S., Grosch, R., Smalla, K., \& Schikora, A. (2017). Interaction between Salmonella and plants: Potential hosts and vectors for human infection. Current Topics in Salmonella and Salmonellosis, 171-191. https://doi.org/ $10.5772 / 67061$

Fraga, C. G., Croft, K. D., Kennedy, D. O., \& Tom $\tilde{A}_{i s-B a r b e r A \tilde{i n}}$, F. A. (2019). The effects of polyphenols and other bioactives on human health. Food \& function, 10(2), 514-528. https://doi.org/10.1039/C8FO01997E

Fukumoto, H., Ishiguro, K., Murashima, T., Yamaki, M., \& Isoi, K. (1994). Structure determination of a kaempferol 3-rhamnosyldiglucoside from Impatiens balsamina. Phytochemistry, 37(5), 1486-1488. https://doi.org/10.1016/S0031-9422(00)904400

Fukumoto, H., Yamaki, M., Isoi, K., \& Ishiguro, K. (1996). Antianaphylactic effects of the principal compounds from the white petals of Impatiens balsamina L. Phytotherapy Research, 10(3), 202-206. https://doi.org/10.1002/(SICI)1099-1573(199605)10:3\% 3C202::AID-PTR805\%3E3.0.CO;2-0

Ganeshaiah, K. N.. UAS, Bangalore. Kailash, B. R., ATREE, Bangalore. Impatiens bicolor Royle [online] India Biodiversity Portal, Species Page: Available at: https://in diabiodiversity.org/species/show/230006 Accessed date Jun 3, 2020.

Gil, M. I., Amodio, M. L., \& Colelli, G. (2020). CA/MA on bioactive compounds. Controlled and modified atmospheres for fresh and fresh-cut produce. Academic Press. https://doi.org/10.1016/B978-0-12-804599-2.00008-9

Gomes, S., Belo, A. T., Alvarenga, N., Dias, J., Lage, P., Pinheiro, C., et al. (2019). Characterization of Cynara cardunculus L. flower from Alentejo as a coagulant agent for cheesemaking. International Dairy Journal, 91, 178-184. https://doi.org/ 10.1016/j.idairyj.2018.09.010

Gostin, A.-I., \& Waisundara, V. Y. (2019). Edible flowers as functional food: A review on artichoke (Cynara cardunculus L.). Trends in Food Science \& Technology, 86, 381-391. https://doi.org/10.1016/j.tifs.2019.02.015 
Goto, T., \& Kondo, T. (1991). Structure and molecular stacking of anthocyanins flower color variation. Angewandte Chemie International Edition in English, 30(1), 17-33. https://doi.org/10.1002/anie.199100171

Grajeda-Iglesias, C., Salas, E., Barouh, N., BarÃ®a, B., \& Figueroa-Espinoza, M. C. (2017) Lipophilization and MS characterization of the main anthocyanins purified from hibiscus flowers. Food Chemistry, 230, 189-194. https://doi.org/10.1016/j. foodchem.2017.02.140

Grey-Wilson, C. (1980). Impatiens of Africa. CRC Press.

Gunawardana, S. L. A., \& e Jayasuriya, W. J. A. B. N. (2019). Medicinally important herbal flowers in Sri Lanka. Evidence-based Complementary and Alternative Medicine. https://doi.org/10.1155/2019/2321961, 2019.

Hagen, C. W., Jr. (1966). The differentiation of pigmentation in flower parts. I. The flavonoid pigments of Impatiens balsamina, genotype IIHHPrPr, and their distribution within the plant. American Journal of Botany, 53(1), 46-54. https://doi. org/10.1002/j.1537-2197.1966.tb07296.x

Harmayani, E., Anal, A. K., Wichienchot, S., Bhat, R., Gardjito, M., Santoso, U., \& Payyappallimana, U. (2019). Healthy food traditions of Asia: Exploratory case studies from Indonesia, Thailand, Malaysia, and Nepal. Journal of Ethnic Foods, 6(1), 1. https://doi.org/10.1186/s42779-019-0002-x

Hasan, A., \& Tahir, M. N. (2005). Flavonoids from the leaves of Impatiens bicolor. Turkish Journal of Chemistry, 29(1), 65-70.

Hatcher, P. E., Wilkinson, M. J., Albani, M. C., \& Hebbern, C. A. (2004). Conserving marginal populations of the food plant (Impatiens noli-tangere) of an endangered moth (Eustroma reticulatum) in a changing climate. Biological Conservation, 116(3), 305-317. https://doi.org/10.1016/S0006-3207(03)00200-3

Hernández, I., Alegre, L., Van Breusegem, F., \& MunnÃ®-Bosch, S. (2009). How relevant are flavonoids as antioxidants in plants? Trends in Plant Science, 14(3), 125-132. https://doi.org/10.1016/j.tplants.2008.12.003

Hooker, J. D., \& Thomson, T. (1859). Præcursores ad Floram Indicam. Balsamineæ. Botanical journal of the Linnean Society, 4(15), 106-157.

Hromádková, Z., Koštálová, Z., Vrchotová, N., \& Ebringerová, A. (2014). Non-cellulosic polysaccharides from the leaves of small balsam (Impatiens parviflora DC. Carbohydrate Research, 389, 147-153. https://doi.org/10.1016/j.carres.2014.01.016

Hua, L., Peng, Z., Chia, L. S., Goh, N. K., \& Tan, S. N. (2001). Separation of kaempferols in Impatiens balsamina flowers by capillary electrophoresis with electrochemical detection. Journal of Chromatography A, 909(2), 297-303. https://doi.org/10.1016/ S0021-9673(00)01102-X

Imam, M. Z., Nahar, N., Akter, S., \& Rana, M. S. (2012). Antinociceptive activity of methanol extract of flowers of Impatiens balsamina. Journal of Ethnopharmacology, 142(3), 804-810. https://doi.org/10.1016/j.jep.2012.06.004

Ishiguro, K., Fukumoto, H., Murashima, T., Kuriyama, M., Semma, M., \& Isoi, K. (1992) Antianaphylactic effects of the ethanolic extract from the petals of Impatiens balsamina L. in mice. Phytotherapy Research, 6(2), 112-113. https://doi.org/ $10.1002 /$ ptr.2650060213

Jimenez-Gonzalez, O., Ruiz-Espinosa, H., Luna-Guevara, J. J., Ochoa-Velasco, C. E., Vital, D. L., \& Luna-Guevara, M. L. (2018). A potential natural coloring agent with antioxidant properties: Microencapsulates of Renealmia alpinia (Rottb.) Maas fruit pericarp. NFS journal, 13, 1-9. https://doi.org/10.1016/j.nfs.2018.08.001

John, S. A., \& Koperuncholan, M. (2012). Antibacterial Activities of various solvent extracts from Impatiens balsamina. International Journal of Pharma and Bio Sciences, 3 (2), 401-406.

Ju, P. J., Kong, D. Y., \& Li, X. B. (2007). Advances of study on the chemical constituents and pharmacological effects of Impatiens balsamina L. [J]. Journal of Shenyang Pharmaceutical University, 5.

Kang, S. N., Goo, Y. M., Yang, M. R., Ibrahim, R. I. H., Cho, J. H., Kim, I. S., et al. (2013). Antioxidant and antimicrobial activities of ethanol extract from the stem and leaf of Impatiens balsamina L. (Balsaminaceae) at different harvest times. Molecules, 18(6), 6356-6365. https://doi.org/10.3390/molecules18066356

Kelley, K. M., Behe, B. K., Biernbaum, J. A., \& Poff, K. L. (2001a). Consumer preference for edible-flower color, container size, and price. HortScience, 36(4), 801-804. https://doi.org/10.21273/HORTSCI.36.4.801

Kelley, K. M., Behe, B. K., Biernbaum, J. A., \& Poff, K. L. (2001b). Consumer ratings of edible flower quality, mix, and color. HortTechnology, 11(4), 644-647. https://doi. org/10.21273/HORTTECH.11.4.644

Kelley, K. M., Behe, B. K., Biernbaum, J. A., \& Poff, K. L. (2002). Combinations of colors and species of containerized edible flowers: Effect on consumer preferences. HortScience, 37(1), 218-221. https://doi.org/10.21273/HORTSCI.37.1.218

Kelley, K. M., Cameron, A. C., Biernbaum, J. A., \& Poff, K. L. (2003). Effect of storage temperature on the quality of edible flowers. Postharvest Biology and Technology, 27 (3), 341-344. https://doi.org/10.1016/S0925-5214(02)00096-0

Khoo, H. E., Azlan, A., Tang, S. T., \& Lim, S. M. (2017). Anthocyanidins and anthocyanins: Colored pigments as food, pharmaceutical ingredients, and the potential health benefits. Food \& Nutrition Research, 61(1), 1361779. https://doi. org/10.1080/16546628.2017.1361779

Kim, C. S., Bae, M., Oh, J., Subedi, L., Suh, W. S., Choi, S. Z., \& Lee, K. R. (2017). Antineurodegenerative biflavonoid glycosides from Impatiens balsamina. Journal of Natural Products, 80(2), 471-478. https://doi.org/10.1021/acs.jnatprod.6b00981

Kim, D. H., Lee, T. H., Subedi, L., Kim, S. Y., \& Lee, K. R. (2019). Chemical constituents of Impatiens balsamina stems and their biological activities. Natural Product Sciences, 25(2), 130-135. https://doi.org/10.20307/nps.2019.25.2.130

Kim, C. S., Subedi, L., Kim, S. Y., Choi, S. U., Choi, S. Z., Son, M. W., et al. (2015). Two new phenolic compounds from the white flower of Impatiens balsamina. Phytochemistry Letters, 14, 215-220. https://doi.org/10.1016/j.phytol.2015.10.014

Kinupp, V. F. L. H. J. (2014). Unconventional Food Plants (PANC) in Brazil: Identification guide, nutritional aspects and illustrated recipes (Vol. 1). Plantarum Institute of Flora Studies Ltda.
Klein, A. O., \& Hagen, C. W., Jr. (1961). Anthocyanin production in detached petals of Impatiens balsamina L. Plant Physiology, 36(1), 1. https://doi.org/10.1104/pp.36.1.1

Klinkenberg, B. (2013). E-flora BC: Electronic atlas of the flora of British columbia. Lab for advanced spatial analysis. Vancouver, British Columbia, Canada: Department of Geography, University of British Columbia. Website http://linnet.geog.ubc.ca/Atlas /Atlas.aspx? sciname=Impatiens + aurella.

Klozová, E., \& Rokosová, K. (1961). Anthocyanins of Impatiens holstii. Biologia Plantarum, 3(4), 291. https://doi.org/10.1007/BF02933074

Koike, A. C. R. (2015). Compostos bioativos em flores comestiveis processadas por radiação. Doctoral dissertation. Universidade de SÃ£o Paulo.

Koike, A., Antonio, A. L., Ferreira, I. C. F. R., \& Villavicencio, A. L. C. H. (2014). Flores comestíveis: Múltiplas utilizações do mais belo da natureza. Vida Rural, 1801, 40-42.

Lachno, A. S., Dutra, R., Severo, J., dos Santos Oliveira, M., \& de Oliveira, L. R. C. (2019). Bioaditivos e aditivos naturais em alimentos: Corantes, antioxidantes e aromatizantes. Boletim Técnico-Científico, 5(2).

Lawrence, W. J. C., Price, J. R., Robinson, G. M., \& Robinson, R. (1939). The distribution of anthocyanins in flowers, fruits and leaves. Philosophical Transactions of the Royal Society of London. Series B, Biological Sciences, 230(567), 149-178. https://doi.org/ $10.1098 /$ rstb.1939.0006

Li, Q., Cao, J., Yuan, W., Li, M., Yang, L., Sun, Y., et al. (2017). New triterpene saponins from flowers of Impatiens balsamina L. and their anti-hepatic fibrosis activity. Journal of Functional Foods, 33, 188-193. https://doi.org/10.1016/j.jff.2017.03.033

Li, Q., Guo, Z., Wang, K., Zhang, X., Lou, Y., \& Zhao, Y. Q. (2015a). Two new 1, 4naphthoquinone derivatives from Impatiens balsamina L. flowers. Phytochemistry Letters, 14, 8-11. https://doi.org/10.1016/j.phytol.2015.08.011

Lim, Y. H., Kim, I. H., \& Seo, J. J. (2007). In vitro activity of kaempferol isolated from the Impatiens balsamina alone and in combination with erythromycin or clindamycin against Propionibacterium acnes. Journal of Microbiology, 45(5), 473-477.

Liu, X. F., Xiang, L. L., Yin, X. R., Grierson, D., Li, F., \& Chen, K. S. (2015). The identification of a MYB transcription factor controlling anthocyanin biosynthesis regulation in Chrysanthemum flowers. Scientia Horticulturae, 194, 278-285. https:// doi.org/10.1016/j.scienta.2015.08.018

Li, Q., Zhang, X., Cao, J., Guo, Z., Lou, Y., Ding, M., et al. (2015b). Depside derivatives with anti-hepatic fibrosis and anti-diabetic activities from Impatiens balsamina L. flowers. Fitoterapia, 105, 234-239. https://doi.org/10.1016/j.fitote.2015.07.007

Lobstein, A., Brenne, X., Feist, E., Metz, N., Weniger, B., \& Anton, R. (2001). Quantitative determination of naphthoquinones of Impatiens species. Phytochemical Analysis, 12 (3), 202-205. https://doi.org/10.1002/pca.574

López, C. J., Caleja, C., Prieto, M. A., Barreiro, M. F., Barros, L., \& Ferreira, I. C. F. R. (2018). Optimization and comparison of heat and ultrasound assisted extraction techniques to obtain anthocyanin compounds from Arbutus unedo L. Fruits. Food Chemistry, 264, 81-91. https://doi.org/10.1016/j.foodchem.2018.04.103

Lu, B., Li, M., \& Yin, R. (2016). Phytochemical content, health benefits, and toxicology of common edible flowers: A review (2000-2015). Critical Reviews in Food Science and Nutrition, 56(sup1), S130-S148. https://doi.org/10.1080/10408398.2015.1078276

Mahyun, F., Kusuma, A. P., \& Anshory, H. (2018). Formulation peel-off gel mask of Impatiens balsamina L. as an antibactery against Staphylococcus aureus. Jurnal Kedokteran dan Kesehatan Indonesia, 9(3), 168-174.

Manikandan, A., Rajendran, R., Abirami, M., \& Kongarasi, K. (2016). Antimicrobial activity and phytochemical analysis of Impatiens balsamina seed (Kaci-T-Tumpai) collected from coimbatore district, Tamil nadu, India. International Journal of Pharmaceutical Sciences and Research, 7(12), 5039.

Mansell, R. L., \& Kemerer, V. L. (1970). Qualitative and quantitative comparisons of hydroxycinnamic acid derivatives in petals of the red (llHHPrPr), white (llhhpp) and purple (LLhhPrPr) genotypes of Impatiens balsamina. Phytochemistry, 9(8), 1751-1755. https://doi.org/10.1016/S0031-9422(00)85587-9

Martins, A., Barros, L., Carvalho, A. M., Santos-Buelga, C., Fernandes, I. P., Barreiro, M. F., et al. (2013). Extratos fenólicos de flores de Rubus ulmifolius Schoot: Caracterização química, microencapsulação e incorporação em iogurtes para benefícios antioxidants. Encontro de Jovens Investigadores do Instituto Politécnico de Bragança. http://hdl.handle.net/10198/9408.

Matthews, J., Beringen, R., Boer, E., Duistermaat, H., Odé, B., Van Valkenburg, J. L. C. H, et al. (2015). Risks and management of non-native Impatiens species in the Netherlands. Radboud Repository. https://hdl.handle.net/2066/149286.

Matyjaszczyk, E., \& Śmiechowska, M. (2019). Edible flowers. Benefits and risks pertaining to their consumption. Trends in Food Science \& Technology, 91, 670-674. https://doi.org/10.1016/j.tifs.2019.07.017

Menegaes, J. F., dos Santos, O. S., \& Londero, F. A. A. (2014). Produção hidropônica de nastúrcio como flores comestíveis.

Mitchell, M. J., Brescia, A. I., Smith, S. L., \& Morgan, E. D. (2007). Effects of the compounds 2â€methoxynaphthoquinone, 2â€propoxynaphthoquinone, and 2â€isopropoxynaphthoquinone on ecdysone 20â€monooxygenase activity. Archives of Insect Biochemistry and Physiology: Published in Collaboration with the Entomological Society of America, 66(1), 45-52. https://doi.org/10.1002/arch.20196

Mlcek, J., \& Rop, O. (2011). Fresh edible flowers of ornamental plants - A new source of nutraceutical foods. Trends in Food Science \& Technology, 22(10), 561-569. https:// doi.org/10.1016/j.tifs.2011.04.006

de Morais, J. S., Sant'Ana, A. S., Dantas, A. M., Silva, B. S., Lima, M. S., Borges, G. C., et al. (2020). Antioxidant activity and bioaccessibility of phenolic compounds in white, red, blue, purple, yellow and orange edible flowers through a simulated intestinal barrier. Food Research International, 131, 109046. https://doi.org/ 10.1016/j.foodres.2020.109046

Morgan, R. J. (2007). Impatiens: The vibrant world of busy lizzies, balsams, and touch-menots. Portland, OR; EUA: Timber Press.

Motz, V. A., Bowers, C. P., Kneubehl, A. R., Lendrum, E. C., Young, L. M., \& Kinder, D. H. (2015). Efficacy of the saponin component of Impatiens capensis Meerb. in preventing 
urushiol-induced contact dermatitis. Journal of Ethnopharmacology, 162, 163-167. https://doi.org/10.1016/j.jep.2014.12.024

Mushtaq, M., Anwer, N., Waqar, M. A., Latif, S., Shahid, S. A., \& Azam, A. (2013). Antioxidant, antimicrobial potential and phytochemical attributes of Impatiens edgeworthii. Asian Journal of Chemistry, 25(17), 9800.

Newman, M., \& Kirker, C. L. (2016). Edible flowers: A global history. London, United Kingdom: Reakition Books.

Nisar, M., Qayum, M., Shah, M. R., Kaleem, W. A., Ali, I. H. S. A. N., \& Zia-Ul-Haq, M (2010). Antimicrobial screening of Impatiens bicolor Royle. Pakistan Journal of Botany, 42(1), 523-526.

NYBG. (2010). The New York botanical garden, Impatiens textorii Miq, C. V. Starr virtua herbarium. http://sweetgum.nybg.org/science/vh/specimen-list/?SummaryData=I mpatiens\%20textorii\%20Miq.

Odorizzi, C. M. C., Silva Júnior, A. A., \& Lemos, M. P. (2014). Flores comestíveis: revisão sobre os aspectos nutracêuticos e o uso na alimentação e na gastronomia. Nutrição Brasil, 13(3), 1184-1189.

Ortin, Y., \& Evans, P. (2013). Trans-tetradec-2-enoic acid in Impatiens glandulifera. Synthetic Communications, 43(10), 1404-1412. https://doi.org/10.1080/ 00397911.2011 .635395

Pal, M., \& Biswas, S. (1994). A novel protein accumulated during maturation of the pods of the plant Impatiens balsamina. Molecular and Cellular Biochemistry, 130(2), 111-120. https://doi.org/10.1007/BF01457392

Panjchayupakaranant, P., Noguchi, H., De-Eknamkul, W., \& Sankawa, U. (1995). Naphthoquinones and coumarins from Impatiens balsamina root cultures. Phytochemistry, 40(4), 1141-1143. https://doi.org/10.1016/0031-9422(95)00418-7

Patel, S. U., Osborn, R., Rees, S., \& Thornton, J. M. (1998). Structural studies of Impatiens balsamina antimicrobial protein (Ib-AMP1). Biochemistry, 37(4), 983-990. https://doi.org/10.1021/bi971747d

Patras, A. (2019). Stability and colour evaluation of red cabbage waste hydroethanolic extract in presence of different food additives or ingredients. Food Chemistry, 275, 539-548. https://doi.org/10.1016/j.foodchem.2018.09.100

Paun, G., Neagu, E., Moroeanu, V., Albu, C., Ursu, T. M., Zanfirescu, A., et al. (2018). Anti-inflammatory and antioxidant activities of the Impatiens noli-tangere and Stachys officinalis polyphenolic-rich extracts. Revista Brasileira de Farmacognosia, 28(1), 57-64. https://doi.org/10.1016/j.bjp.2017.10.008

PFAF. (2020). Plants for A Future. Retrieved From https://pfaf.org/user/cmspage.aspx? pageid $=136$. June, 2020.

Pinakin, D. J., Kumar, V., Suri, S., Sharma, R., \& Kaushal, M. (2019). Nutraceutical potential of tree flowers: A comprehensive review on biochemical profile, health benefits, and utilization. Food Research International. https://doi.org/10.1016/j. foodres.2019.108724, 108724.

Pinela, J., Prieto, M. A., Pereira, E., Jabeur, I., Barreiro, M. F., Barros, L., et al. (2019) Optimization of heat-and ultrasound-assisted extraction of anthocyanins from Hibiscus sabdariffa calyces for natural food colorants. Food Chemistry, 275, 309-321. https://doi.org/10.1016/j.foodchem.2018.09.118

Pires, T. C. S. P., Barros, L., Santos-Buelga, C., \& Ferreira, I. C. F. R. (2019). Edible flowers: Emerging components in the diet. Trends in Food Science \& Technology, 93, 244-258. https://doi.org/10.1016/j.tifs.2019.09.020

Pires, T. C., Dias, M. I., Barros, L., \& Ferreira, I. C. (2017). Nutritional and chemical characterization of edible petals and corresponding infusions: Valorization as new food ingredients. Food Chemistry, 220, 337-343. https://doi.org/10.1016/j. foodchem.2016.10.026

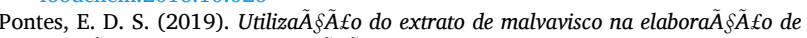
hamb $\tilde{A}^{\circ}$ rguer caprino e avaliaA $\hat{\S} \tilde{A}$ fo do seu potential antioxidante durante o armazenamento refrigerado. Retrieved from http://dspace.sti.ufcg.edu.br:8080/jspui /handle/riufcg/8252. January, 2021.

Puértolas, E., Cregenzán, O., Luengo, E., Álvarez, I., \& Raso, J. (2013). Pulsed-electricfield-assisted extraction of anthocyanins from purple-fleshed potato. Food Chemistry, 136(3-4), 1330-1336. https://doi.org/10.1016/j.foodchem.2012.09.080

Rodrigues, H., Cielo, D. P., GomÃ@z-Corona, C., Silveira, A. A. S., Marchesan, T. A., Galmarini, M. V., et al. (2017). Eating flowers? Exploring attitudes and consumers' representation of edible flowers. Food Research International, 100, 227-234. https:// doi.org/10.1016/j.foodres.2017.08.018

Rodriguez-Amaya, D. B. (2016). Natural food pigments and colorants. Current Opinion in Food Science, 7, 20-26. https://doi.org/10.1016/j.cofs.2015.08.004

Rodríguez-Pérez, C., Segura-Carretero, A., \& del Mar Contreras, M. (2019). Phenolic compounds as natural and multifunctional anti-obesity agents: A review. Critical Reviews in Food Science and Nutrition, 59(8), 1212-1229. https://doi.org/10.1080/ 10408398.2017.1399859

Rop, O., Mlcek, J., Jurikova, T., Neugebauerova, J., \& Vabkova, J. (2012). Edible flowers a new promising source of mineral elements in human nutrition. Molecules, 17(6), 6672-6683. https://doi.org/10.3390/molecules17066672

Rowles, J. L., III, \& Erdman, J. W., Jr. (2020). Carotenoids and their role in cancer prevention. Biochimica et Biophysica Acta (BBA) - Molecular and Cell Biology of Lipids. https://doi.org/10.1016/j.bbalip.2020.158613, 158613.

Santos-Buelga, C., \& González-Paramás, A. M. (2019). Anthocyanins. https://doi.org/ 10.1016/B978-0-08-100596-5.21609-0

Schiozer, A. L., \& Barata, L. E. S. (2013). Estabilidade de corantes e pigmentos de origem vegetal. Revista Fitos, 3(2), 6-24. Retrieved from https://www.arca.fiocruz.br/h andle/icict/19149.

Stefaniak, A., \& Grzeszczuk, M. E. (2019). Nutritional and biological value of five edible flower species. Notulae Botanicae Horti Agrobotanici Cluj-Napoca, 47(1), 128-134. https://doi.org/10.15835/nbha47111136

Su, H. N., Cao, Z. X., Li, J. C., Fan, Y. J., Yang, L. M., \& Zhang, G. (2007). The extractive Technology of natural edible-pigment from the fresh garden balsam. Zhejiang. Chemical Industry, 9, 5. https://doi.org/10.13684/j.cnki.spkj.2007.01.04
Sultan, D. M. D. (2003). Extraction yellow pigments from Impatiens balsamically in xinjiang and A study on its stability. Journal of Xingiiang Normal University (Natural Sciences Edition), 2, 12.

Sun, X., Shim, D. W., Han, J. W., Shin, W. Y., Sim, E. J., Kim, M. K., et al. (2015). Antiinflammatory effect of Impatiens textori Miq. extract via inhibition of NLRP3 inflammasome activation in in vitro and in vivo experimental models. Journal of Ethnopharmacology, 170, 81-87. https://doi.org/10.1016/j.jep.2015.05.001

Su, B. L., Zeng, R., Chen, J. Y., Chen, C. Y., Guo, J. H., \& Huang, C. G. (2012). Antioxidant and antimicrobial properties of various solvent extracts from Impatiens balsamina L. stems. Journal of Food Science, 77(6), C614-C619. https://doi.org/10.1111/j.17503841.2012.02709.x

Szewczyk, K. (2018). Phytochemistry of the genus Impatiens (balsaminaceae): A review. Biochemical Systematics and Ecology, 80, 94-121. https://doi.org/10.1016/j. bse.2018.07.001

Szewczyk, K., Bonikowski, R., MaciÄ...g-Krajewska, A., Abramek, J., \& BoguckaKocka, A. (2018a). Lipophilic components and evaluation of the cytotoxic and antioxidant activities of Impatiens glandulifera Royle and Impatiens noli-tangere L. (Balsaminaceae). Grasas Y Aceites, 69(3), 270.

Szewczyk, K., Heise, E. M., \& Piwowarski, J. P. (2018b). Preliminary characterization and bioactivities of some Impatiens L. water-soluble polysaccharides. Molecules, 23 (3), 631.

Szewczyk, K., Kalemba, D., Komsta, Ł., \& Nowak, R. (2016a). Comparison of the essential oil composition of selected Impatiens species and its antioxidant activities. Molecules, 21(9), 1162. https://doi.org/10.3390/molecules 21091162

Szewczyk, K., \& Olech, M. (2017). Optimization of extraction method for LC-MS based determination of phenolic acid profiles in different Impatiens species. Phytochemistry Letters, 20, 322-330. https://doi.org/10.1016/j.phytol.2017.02.005

Szewczyk, K., Orzelska-Gorka, J., Polakowska, M., \& Biala, G. (2018c). Antinociceptive and antianxiety activity of hydroethanolic extracts of three Impatiens species in mice. Acta Poloniae Pharmaceutica, 75(4), 989-1001.

Szewczyk, K., Sezai Cicek, S., Zidorn, C., \& Granica, S. (2019). Phenolic constituents of the aerial parts of Impatiens glandulifera Royle (Balsaminaceae) and their antioxidant activities. Natural Product Research, 33(19), 2851-2855. https://doi.org/ 10.1080/14786419.2018.1499644

Szewczyk, K., Zidorn, C., Biernasiuk, A., Komsta, Ł., \& Granica, S. (2016b). Polyphenols from Impatiens (Balsaminaceae) and their antioxidant and antimicrobial activities. Industrial Crops and Products, 86, 262-272. https://doi.org/10.1016/j. indcrop.2016.03.053

Tailor, R. H., Acland, D. P., Attenborough, S., Cammue, B. P., Evans, I. J., Osborn, R. W., et al. (1997). A novel family of small cysteine-rich antimicrobial peptides from seed of Impatiens balsamina is derived from a single precursor protein. Journal of Biological Chemistry, 272(39), 24480-24487.

Takahashi, J. A., Rezende, F. A. G. G., Moura, M. A. F., Dominguete, L. C. B., \& Sande, D. (2020). Edible flowers: Bioactive profile and its potential to be used in food development. Food Research International, 129, 108868. https://doi.org/10.1016/j. foodres.2019.108868

Tarone, A. G., Cazarin, C. B. B., \& Junior, M. R. M. (2020). Anthocyanins: New techniques and challenges in microencapsulation. Food Research International, 133 109092. https://doi.org/10.1016/j.foodres.2020.109092

Tatsuzawa, F., Saito, N., Mikanagi, Y., Shinoda, K., Toki, K., Shigihara, A., et al. (2009). An unusual acylated malvidin 3-glucoside from flowers of Impatiens textori Miq. (Balsaminaceae). Phytochemistry, 70(5), 672-674. https://doi.org/10.1016/j. phytochem.2009.03.005

Thakur, M., \& Nozzolillo, C. (1978). Anthocyanin pigmentation in roots of Impatiens species. Canadian Journal of Botany, 56(22), 2898-2903. https://doi.org/10.1139/ b78-347

Thakur, A., Singla, R., \& Jaitak, V. (2015). Coumarins as anticancer agents: A review on synthetic strategies, mechanism of action and SAR studies. European Journal of Medicinal Chemistry, 101, 476-495. https://doi.org/10.1016/j.ejmech.2015.07.010

The Plant List. (2013). Version 1.1. Published on the Internet, Retrieved from htt p://www.theplantlist.org/.

Thevissen, K., FranÃßois, I. E., Sijtsma, L., Van Amerongen, A., Schaaper, W. M., Meloen, R., et al. (2005). Antifungal activity of synthetic peptides derived from Impatiens balsamina antimicrobial peptides Ib-AMP1 and Ib-AMP4. Peptides, 26(7), 1113-1119. https://doi.org/10.1016/j.peptides.2005.01.008

Trinh, L. T. P., Choi, Y.-S., \& Bae, H.-J. (2018). Production of phenolic compounds and biosugars from flower resources via several extraction processes. Industrial Crops and Products, 125, 261-268. https://doi.org/10.1016/j.indcrop.2018.09.008

Tsushiro, K., Kurizaki, A., Watanabe, T., \& Devkota, H. P. (2019). Chemical constituents from the aerial parts of Impatiens hypophylla Makino var. hypophylla. Biochemical Systematics and Ecology, 83, 10-12. https://doi.org/10.1016/j.bse.2018.12.011

Ueda, Y., Oku, H., Iinuma, M., \& Ishiguro, K. (2003). Effects on blood pressure decrease in response to PAF of Impatiens textori M IQ. Biological and Pharmaceutical Bulletin, 26(10), 1505-1507. https://doi.org/10.1248/bpb.26.1505

Ueda, Y., Oku, H., Iinuma, M., \& Ishiguro, K. (2005). Antianaphylactic and antipruritic effects of the flowers of Impatiens textori M IQ. Biological and Pharmaceutical Bulletin, 28(9), 1786-1790. https://doi.org/10.1248/bpb.28.1786

Ueno, N., Takemura, E. I., \& Hayashi, K. (1969). Additional data of the paper chromatographic survey of anthocyanins in the flora of Japan (IV). Studies on anthocyanins, LXI. Bot. Mag. Tokyo, 82, 155-161.

Useful Tropical Plants. (2016). Database search. Retrieved from http://tropical.theferns. info/query.php?full=impatiens.

Vieira, I., PÃ@rez-GÃ $j$ lvez, A., \& Roca, M. (2019). Green natural colorants. Molecules, 24 (1), 154. https://doi.org/10.3390/molecules24010154

Vieira, M. N., Winterhalter, P., \& Jerz, G. (2016). Flavonoids from the flowers of Impatiens glandulifera Royle isolated by high performance countercurrent 
chromatography. Phytochemical Analysis, 27(2), 116-125. https://doi.org/10.1002/ pca. 2606

Wang, T., Li, Q., \& Bi, K. (2018). Bioactive flavonoids in medicinal plants: Structure, activity and biological fate. Asian Journal of Pharmaceutical Sciences, 13(1), 12-23. https://doi.org/10.1016/j.ajps.2017.08.004

Wang, Y. C., Li, W. Y., Wu, D. C., Wang, J. J., Wu, C. H., Liao, J. J., et al. (2011). In vitro activity of 2-methoxy-1, 4-naphthoquinone and stigmasta-7, 22-diene-3 $\hat{\mathrm{I}}^{2}$-ol from Impatiens balsamina L. Against multiple antibiotic-resistant Helicobacter pylori. Evidence-based Complementary and Alternative Medicine. https://doi.org/10.1093/ ecam/nep147, 2011

Washington State. (2020a). Noxious weed control board [Web log post] Retrieved from https://www.nwcb.wa.gov/search/results? q=impatiens.

Washington State. (2020b). Noxious Weed Control Board. Draft written findings on Impatiens parviflora, small-flowered jewelweed [Web log post] Retrieved. https://www. nwcb.wa.gov/pdfs/Impatiens_parviflora_draft_WF.pdf.

Wrischer, M., Ljubesic, N., Prebeg, T., \& e Magnus, V. (1999). The succession of chromoplast structures in Impatiens noli-tangere flowers. PHYTON-HORN, 39, 49-60.

Yamagishi, M., Uchiyama, H., \& Handa, T. (2018). Floral pigmentation pattern in Oriental hybrid lily (Lilium spp.) cultivar 'Dizzy' is caused by transcriptional regulation of anthocyanin biosynthesis genes. Journal of Plant Physiology, 228, 85-91. https://doi.org/10.1016/j.jplph.2018.05.008

Yang, X., Summerhurst, D. K., Koval, S. F., Ficker, C., Smith, M. L., \& Bernards, M. A. (2001). Isolation of an antimicrobial compound from Impatiens balsamina L. using bioassay-guided fractionation. Phytotherapy Research, 15(8), 676-680. https://doi. org/10.1002/ptr.906

Yu, S. X., Janssens, S. B., Zhu, X. Y., Lidén, M., Gao, T. G., \& Wang, W. (2016). Phylogeny of Impatiens (Balsaminaceae): integrating molecular and morphological evidence into a new classification. Cladistics, 32(2), 179-197. https://doi.org/10.1111/ cla. 12119

Zhang, C., Wang, W., Wang, Y., Gao, S., Du, D., Fu, J., et al. (2014). Anthocyanin biosynthesis and accumulation in developing flowers of tree peony (Paeonia suffruticosa) 'Luoyang Hong'. Postharvest Biology and Technology, 97, 11-22. https:// doi.org/10.1016/j.postharvbio.2014.05.019

Zhang, J., Wen, C., Zhang, H., Duan, Y., \& Ma, H. (2019). Recent advances in the extraction of bioactive compounds with subcritical water: A review. Trends in Food Science \& Technology, 95, 183-195. https://doi.org/10.1016/j.tifs.2019.11.018

Zheng, Y., Hu, Y., Liu, K., Lu, Y., Hu, Y., \& Zhou, X. (2019b). Therapeutic effect of Impatiens balsamina, Lawsonia inermis L. and Henna on androgenetic alopecia in mice. Journal of Southern Medical University, 39(11), 1376. https://doi.org/ 10.12122/j.issn.1673-4254.2019.11.17

Zheng, J., Meenu, M., \& Xu, B. (2019). A systematic investigation on free phenolic acids and flavonoids profiles of commonly consumed edible flowers in China. Journal of Pharmaceutical and Biomedical Analysis, 172, 268-277. https://doi.org/10.1016/j. jpba.2019.05.007

Zika, P. F. (2006). The status of Impatiens capensis (balsaminaceae) on the pacific northwest coast. Journal of the Torrey Botanical Society, 133(4), 593-600. https://doi. org/10.3159/1095-5674(2006)133[593: TSOICB]2.0.CO;2 